\title{
قراءة في كتاب: \\ *"الأخلاق المسيحية" \\ نحو علم مسيحيات إسلامي
}

عامر عدنان الحافي

مقدمة:

يعدّ إسماعيل راجي الفاروقي أحد أهم المفكرين المسلمين، الذين درسوا الفكر الديني

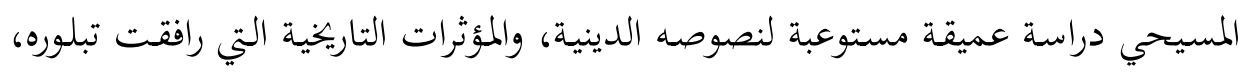

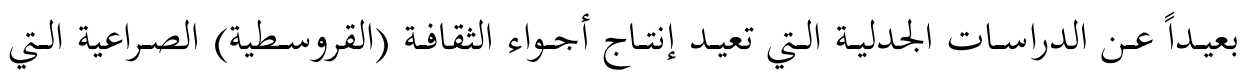

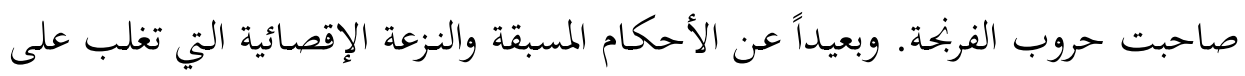

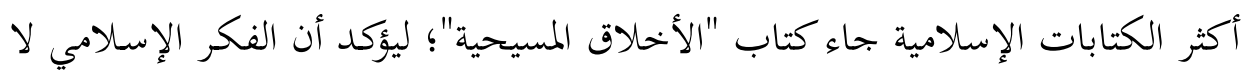

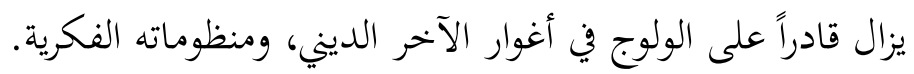

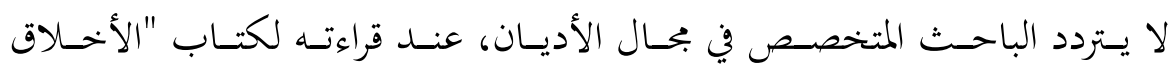

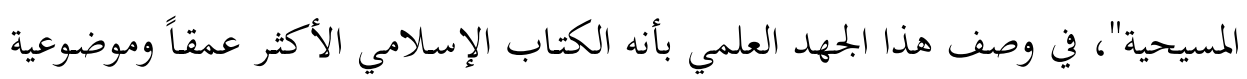

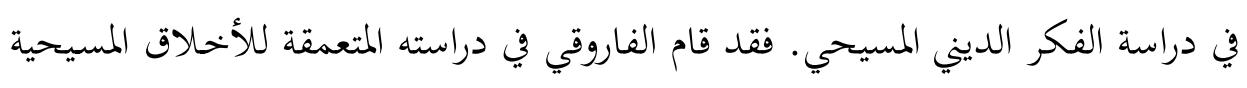

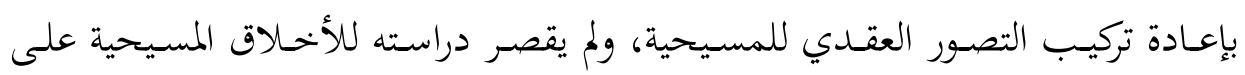

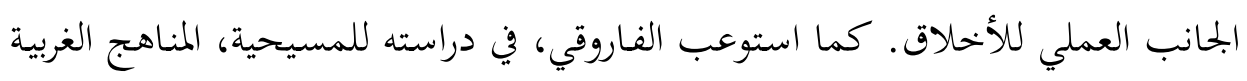

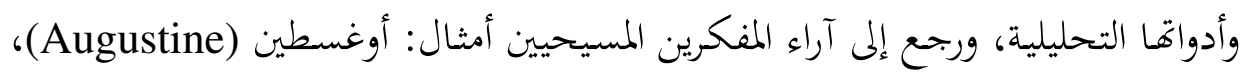

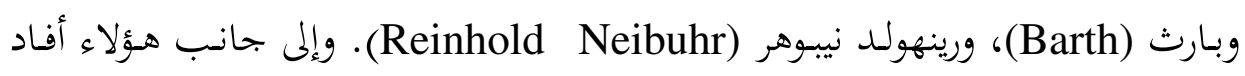

Al-Fauqi, Isma'il, Raji. Christian Ethics: A Historical and Symbolic Analysis of Its

Dominant Ideas, Montreal Canada: McGill University Press, 1967.

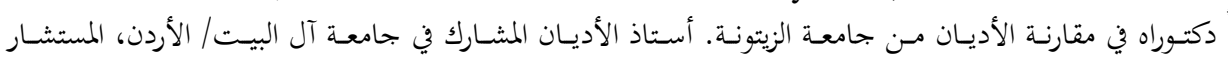

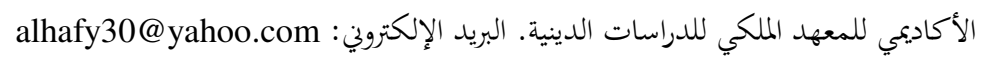

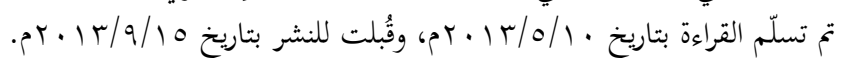


الفاروقي مـن الدراسات الغربية النقدية المعارضة للنظرة المسيحية التقليدية للمسيح، كما هو الحال مع س. هـ. دود (C. H. Dodd). وإلى جانـب التعريـف بأهميـة كتـاب "الأخهالاق المسـيحية" تسـعى هـذه الورقـة إلى

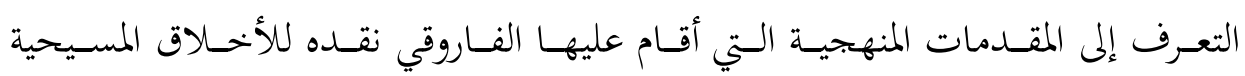

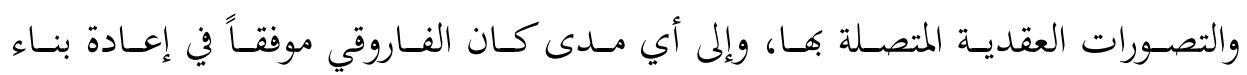

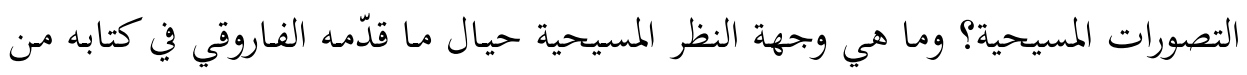
نقد عميق للمسيحية؟

\section{محتويات الكتاب}

يُعـدُّ كتـاب "الأخهالاق المسـيحية" دراسـةً إسـلامية معاصرة ومتخصصـة في الأخهلاق المسيحية، امتازت بالعمق، والتوثيق، والتمكن من تقنيات البحث العلمي التي يستعملها الغربيون في دراساتم. وامتاز الكتاب كذلك بالمعرفة العميقة للنصوص المسيحية المقدسة.

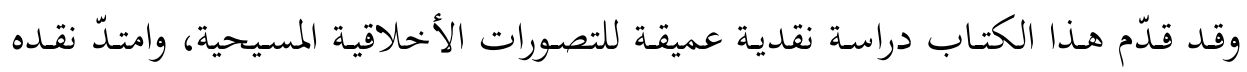
ليطال بعض الأصول العقدية للمسيحية، مثل عقيدة الخطيئة الأصلية. وسعى الفـاروقي

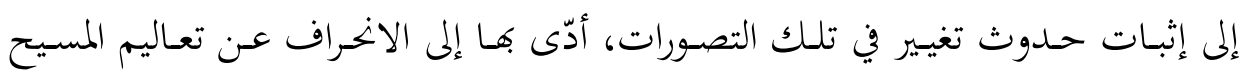

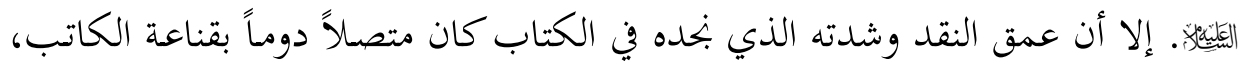
والتزامه بقيم الحوار العلمي مع أتباع الديانة المسيحية.

اشتمل الكتاب، على مقدمـة وقسمين؛ تناولت المقدمة المحاور الآتية: خطاب إلى

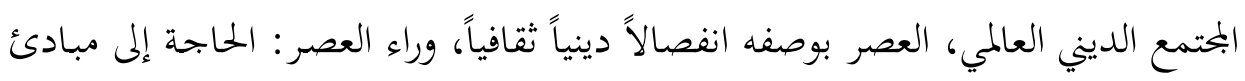

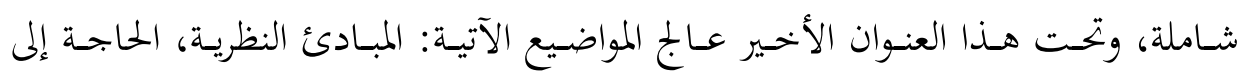

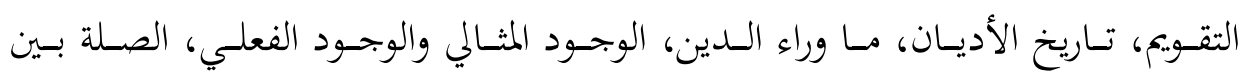

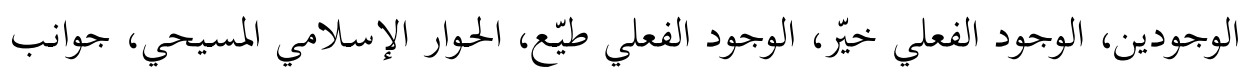
النقص في علم المسيحية المقارن، بيشوب ستيفن (Bishop Stephen)، هندريك كرايمر

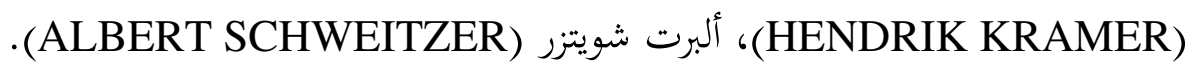




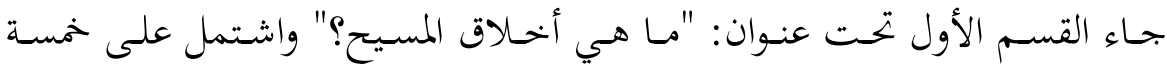

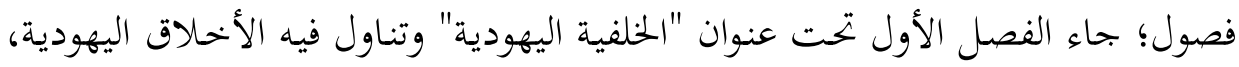

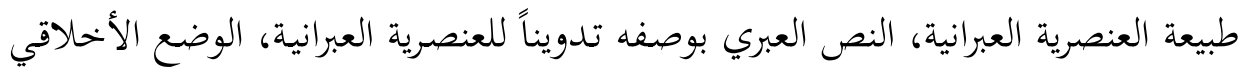

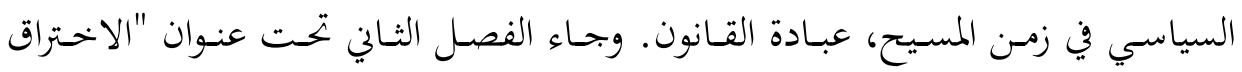

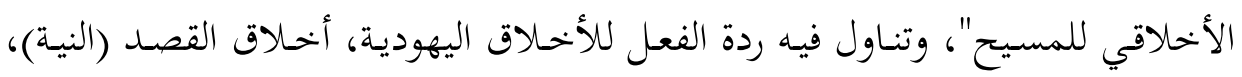

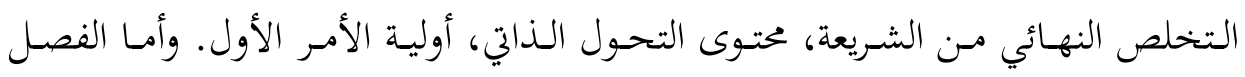

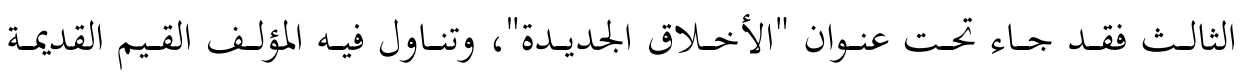

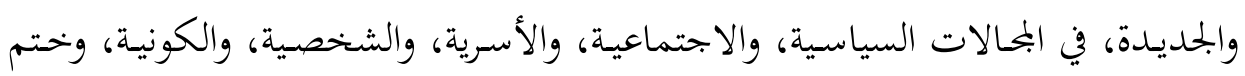

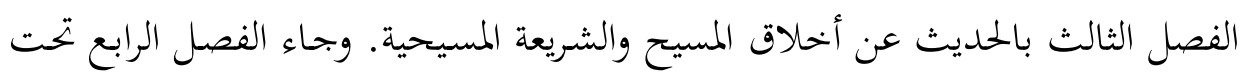
عنوان: "الصوفية الموازية". وتناول فيه: التوازي، وتفسيره.

القسم الثاني من الكتاب جحاء تحت عنوان: إعـادة التقويم المسيحي، وتناول ثلاثة

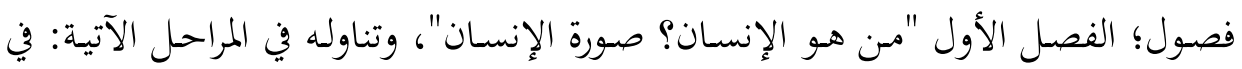
المسيحية الهلينية، ومسيحية ما قبل الإصلاح، والمسيحية الإصلاحية، والمسيحية المعاصرة.

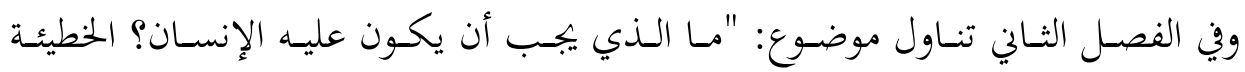

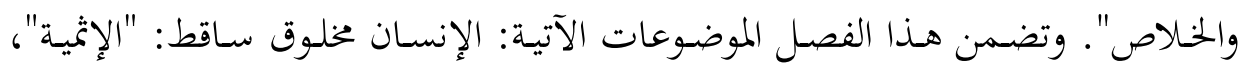

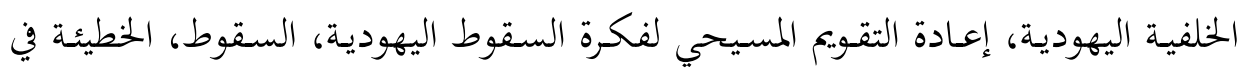

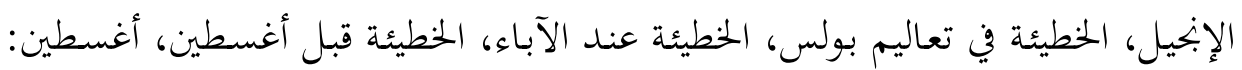

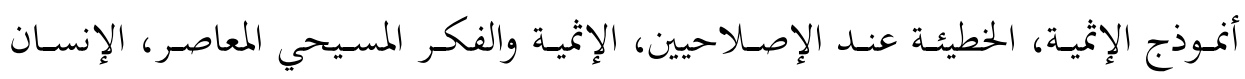

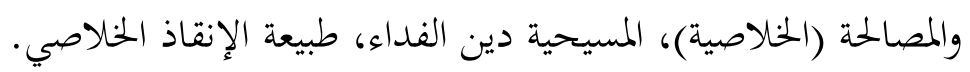

الفصل الثالث وعنوانه: "ما الذي يجب أن يكون عليه الإنسان، الكنيسة والبحتمع".

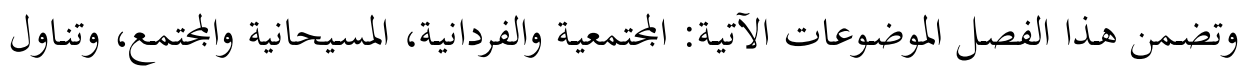

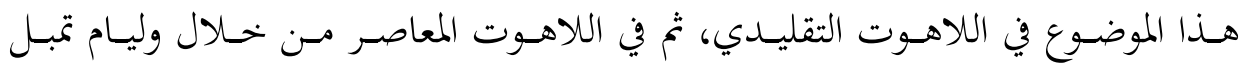

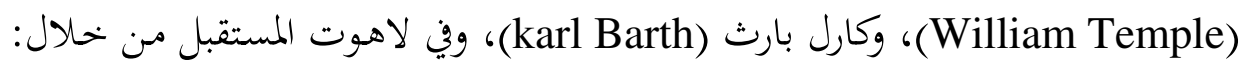

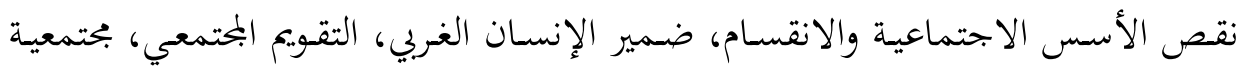
رينهولد نيبوهر (reinhold Niebuhar). 


\section{ما هي أخلاق المسيح؟}

تنـاول الفـاروقي في الفصـل الأول مـن القسـم الأول مـن الكتـاب موضـوع الأخهلاق

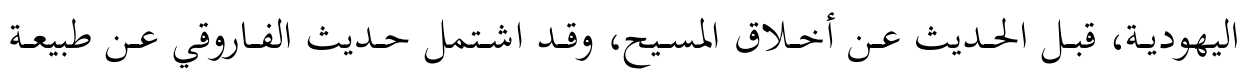

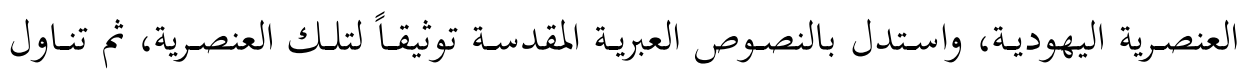
الأوضاع الأخلاقية التي كانت سائدة في زمن المسيح، فالمسيح قد وُلد بين اليهود، وتأثر بأخلاقهم وظروفهم، وقد بدأ دعوته من البحتمع اليهودي.

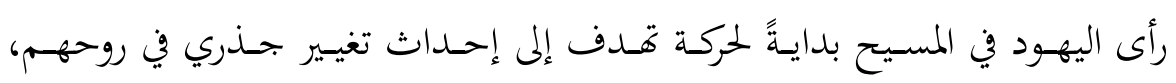

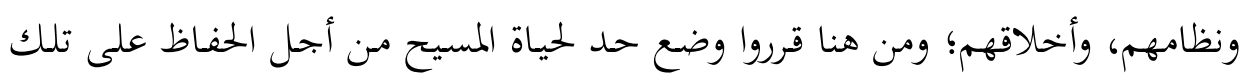
الروح وذلك النظام. ولمعرفة أية أخحلاق كانت وراء تلك المعارضة اليهودية للأخلاق التي وروني

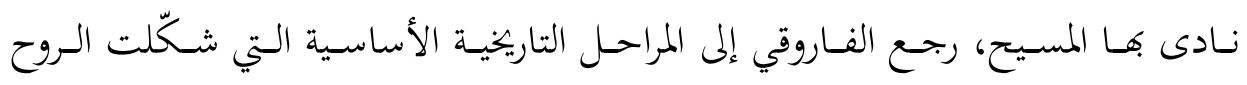

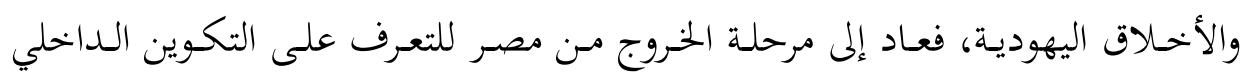
لألخاق اليهودية.

وقد أثبـت الفـاروقي، بعد عملية الاستقراء، أن الأخهاق اليهودية قد تأثرت بالقيم

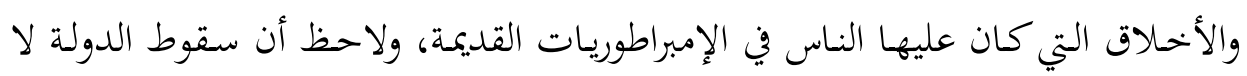

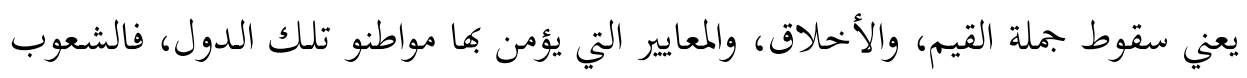

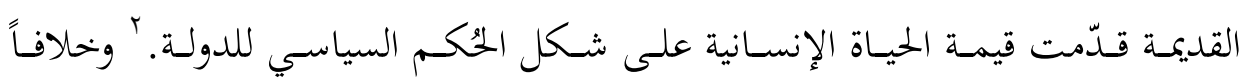

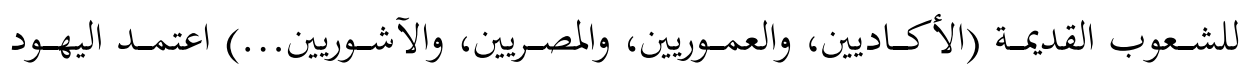

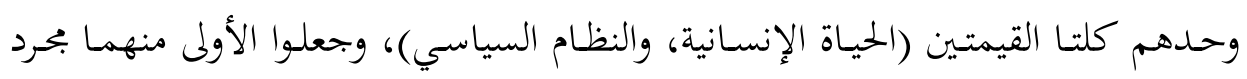

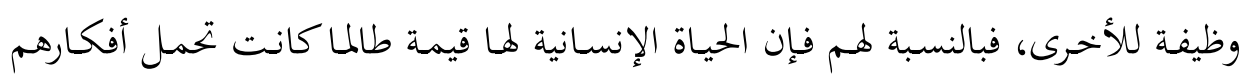

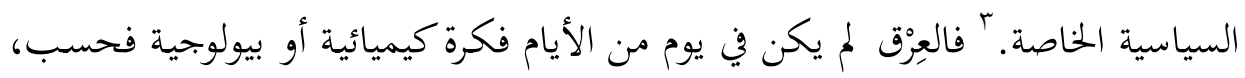

${ }^{1}$ Ismail Ragi A.alfaruqi. Christian ethics a historical and systematic analysis of its dominant ideas. Montreal. Mc Gill University press. 1967. p50

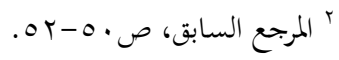

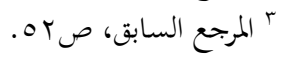




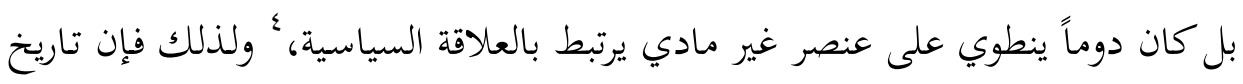
اليهـود إلى اليوم هـو قصـة لتلـك العنصـرية المنطويـة على كثير مـن الغمـوض والإبهـام،

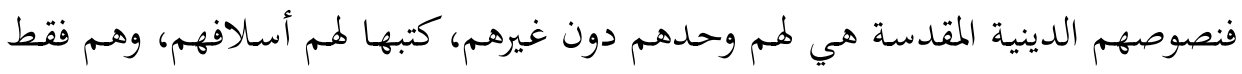
من يفهمون تلك الكتابات.

ينطلق الفاروقي من مقدمة أساسية في سياق تعرضه للعنصرية اليهودية، وهي أن ثورة

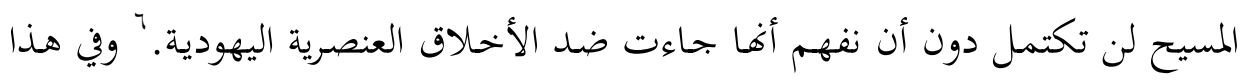

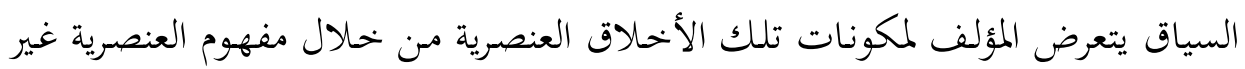
المعللة، وهنا يطرح سؤالاً يؤكد من خلاله مضمون لمون تلك تلك العنصرية. لماذا اختار الله إبراهيم والعبرانيين?

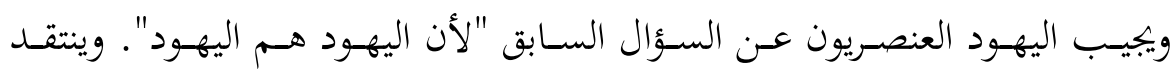

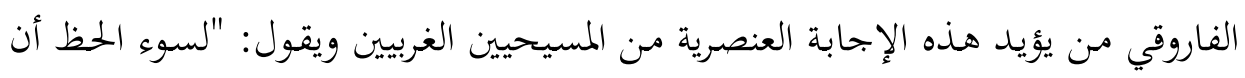

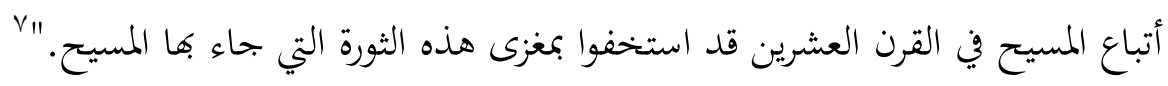

\section{الاختراق الأخلاقي للمسيح}

تحدث المؤلف في الفصل الثاني من القسم الأول عن الاختراق الأخلاقي للمسيح،

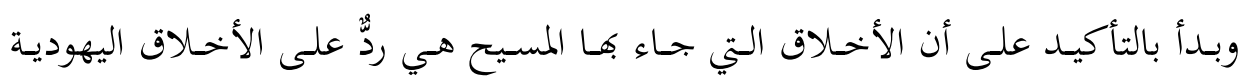

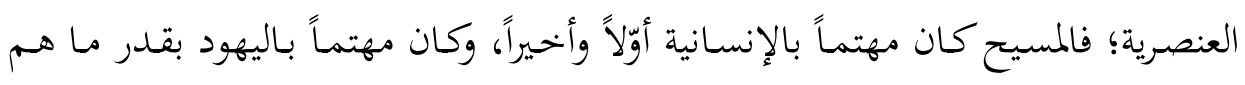

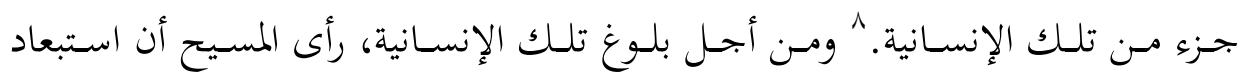

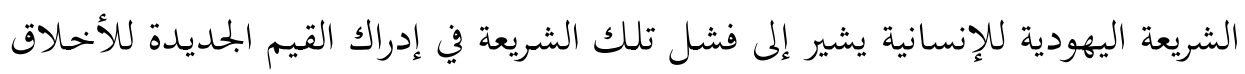

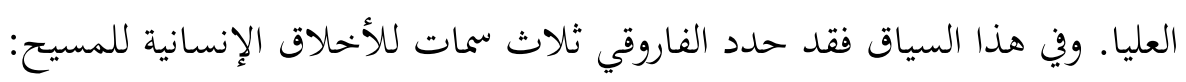

$$
\begin{aligned}
& \text { ؛ المرجع السابق، ص صبه. }
\end{aligned}
$$

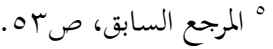

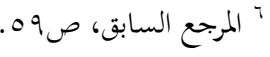

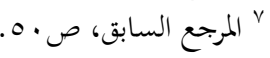

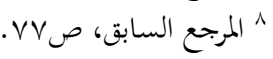


1. أن أخلاق المسيح ترتكز حول الذات الخاصة وشخصية الفرد. r. أهخا تحقق القيم السامية.

\section{r. أغها تحقق الإنسانية الشاملة (ذات نطاق إنساني).?}

وهــه السـمات الأخلاقيـة الإنسـانية تخالف الأخـالاق اليهوديـة التي تتمحسور حـول اليهود فقط دون غيرهم.

شهدت فلسطين صعود الإمبراطورية اليونانية واهيارها. وشهدت قبل ذلك تعاقب الإمبراطوريتين البابلية والفارسية، وفي خضم ذلك كانت الأخهاق التوحيدية الإبراهيمية

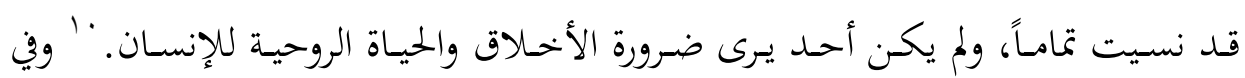
مقابل شريعة التوراة التي تسعى إلى ارتكاب الجحرائم، لتحقيق الازدهار، والوحدة والهوية، لفت المسيح الانتباه إلى قانون آخر أعمق غوراً وأكثر أهمية، وهو القانون الأخلاقي. ولأنه قانون "أخلاقي" فليس من طبيعته أن يُصبح تشريعاً، فطبيعته تخالف جميع المظاهر الخارجيـة، لأن موضوعه هو النفس، الوجود الداخلي للإنساني، الذي لا يصل إليه إلا

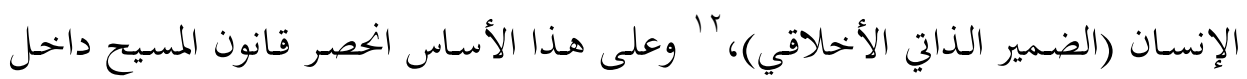
نطاق النفس الداخلية. فالنفس هي ساحة الصراع لجميع القيم الأخلاقية العليا، ومـن أجل ذلك يجـب أن يكون أول مـا يؤخــ بالاعتبـار هو القضـايا الأخلاقية، ومـن خهلال هذه المنطقة الضيقة، أوجد قانون المسيح كل ما يلزم لصياغة الفهم الكامل، فما هو غير

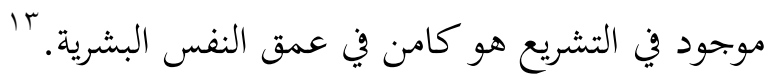
وتحقق الأخهاق رُوقيّها الجلديد والعظيم عندما تغيّر تركيزهـا مـن (الإرادة الجماعيـة)، بالنجـاة إلى (الإرادة الشخصية)، مـن خـلال التغلب على الـنفس وبـذلها، وجعلهـا إرادة

$$
\begin{aligned}
& \text { " المرجع السابق، صVV. }
\end{aligned}
$$

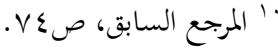

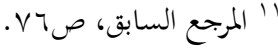

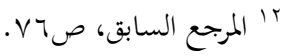

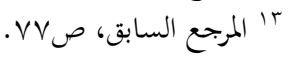


شخصـية للحـب. ؛ُ أمـا القـانون اليهـودي، فقـــ ابحـهـ إلى الاهتمـام بـابلمتمع اليهـودي (إسرائيل) من أجل تحقيق أهدافه، وقد جعل هذا القانون (إسرائيل) فوق الجنس البشري كله، وكرّس فكرة الانفصال، وجعلها شرطاً للحفاظ على الهوية المختلفة عن (الغو.يم). فالشريعة اليهوديـة جـاءت للحفـاظ على النقـاء العِرقِي والانفصـال، وأمـا القـانون الجحديد للمسيح، فقد عدّ ذلك تعصباً ولا معنى له، وانفصالاً يستحق الإدانة الصارمة؛ المسيح أن كل إنسان هو شخصية تحظى بالكرامة الكاملة للخلق، وهـذا منـاقض تماماً للانفصالية اليهودية والانتقائية العنصرية. 'الوقد أعلن المسيح الأخوة العالمية لإِنسان، وأخذات هذه العالمية ابتحاهها من البحث العميق لمعنى الشريعة، وتأكيد النظرة الداخلية لأخحلاق

كان المسـيح مراقبـاً متحمسـاً ودارسـاً مهتمـاً بمنظومـة الأفكار المحيطة بـه، لا وكـان

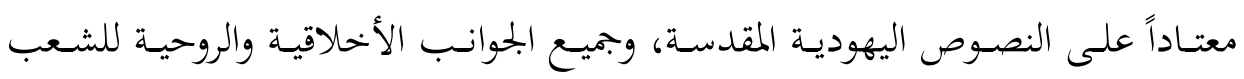
اليهودي. وقد بجاوز المسيح ذلك، ليكتشف أين وقع الضلال والابتعاد عن الأخهاق

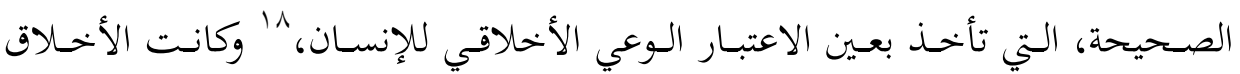

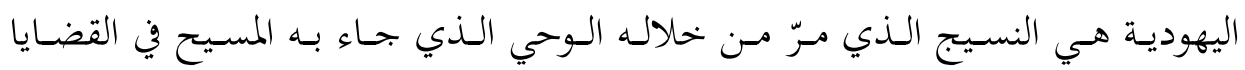

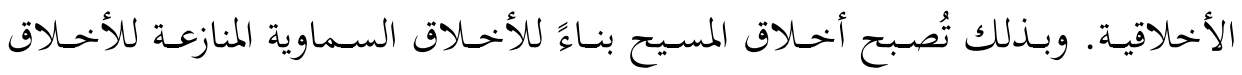

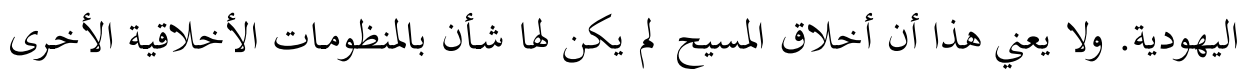

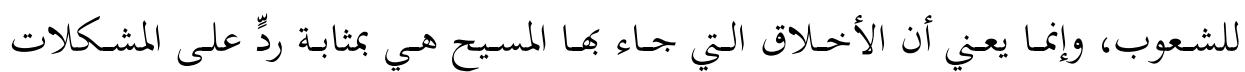

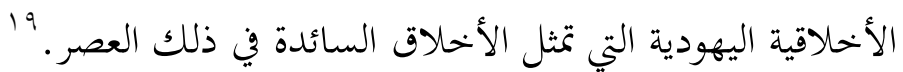

إن الأخلاق التي جاء بها المسيح تختلف عن الشريعة اليهودية؛ إذ تقوم على أسس

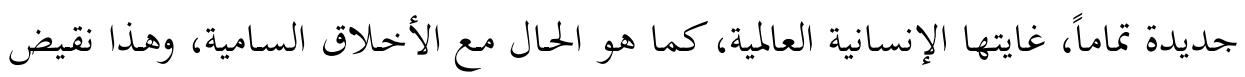

$$
\begin{aligned}
& \text { \& ألمرجع السابق، صVV. }
\end{aligned}
$$

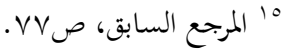

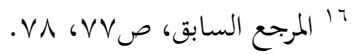

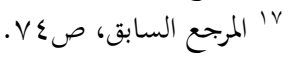

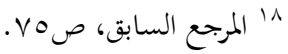

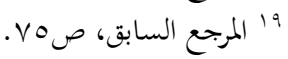


المثـال الـذي تتضـمنه الشـيعة اليهوديـة، الذذي يقـوم على الربـاط الاجتمـاعي، وهـي في

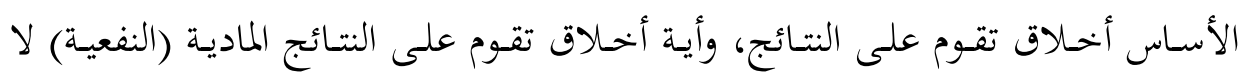

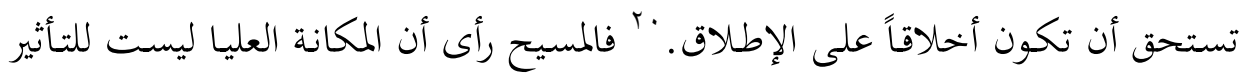

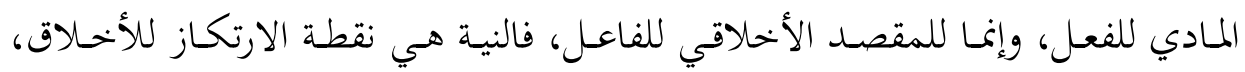

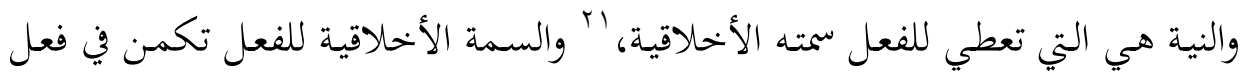
الإرادة التي أرادته، والقيمـة النفعيـة للنتيجـة لا تمسس نوعيـة الفعـل التي تبقى مسـألة نيـة

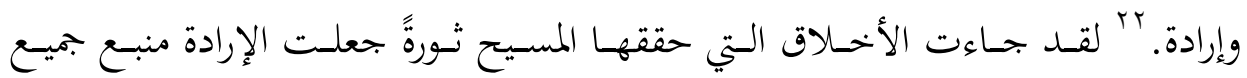
التصرفات، فبإذاكانت الإرادة حسنة قوية، مهتدية، سيكون عملها كذلك، "من ثمارهم

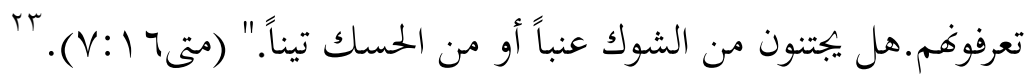

\section{التخلُّص النهائي من الشريعة}

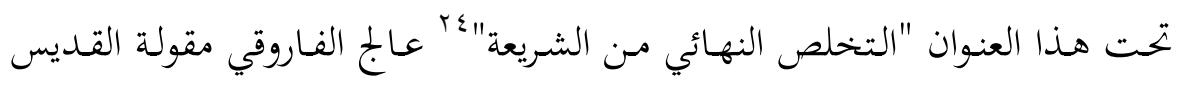
أوغسطين: "أحبـبِ الله وافعلْ مـا تشاء". وهنا يشير الفاروقي إلى أن هناك تحولاً جوهرياً

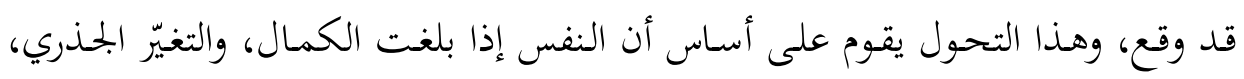

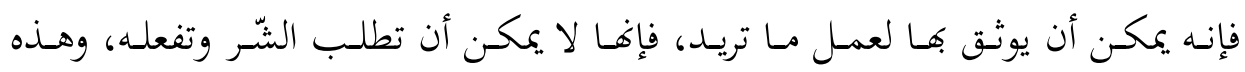

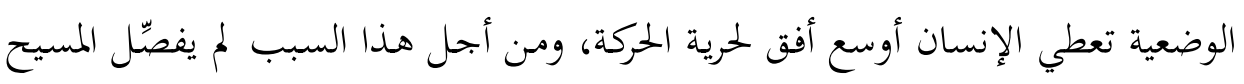

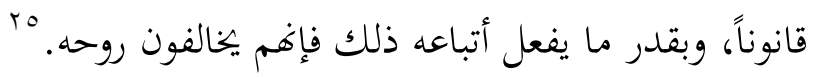

والموضـوع الأهـم في نظر المسـيح هـو تحويل النفس الإنسـانية جـذرياً؛ أي مضـمون التحول الذاتي؛ إذ ينتقد الفاروقي القول بأن جوهر المسيحية موجود في القاعدة الذهبية

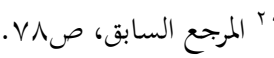

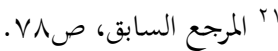

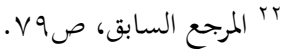

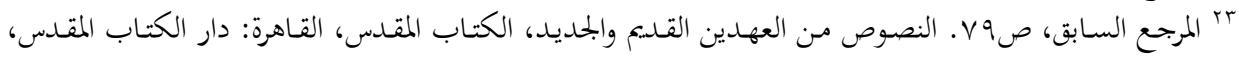

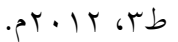

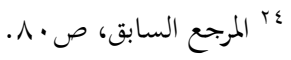

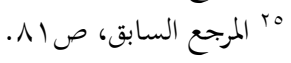




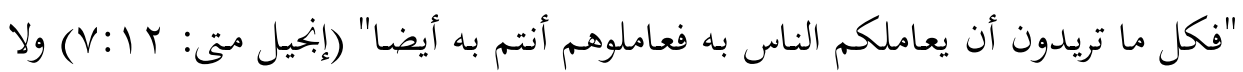

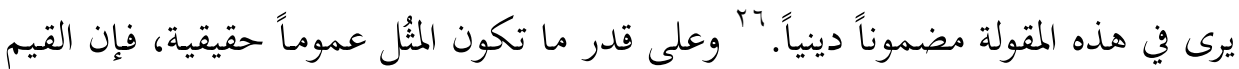

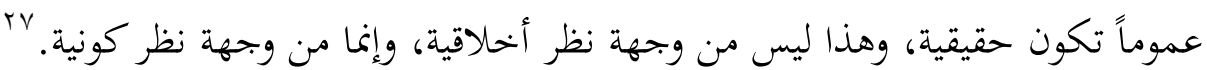
والأخلاق هي الأكثر شمولاً، والأصل الأهم، فهي السُّلطة الأخيرة للصواب والخطأ،

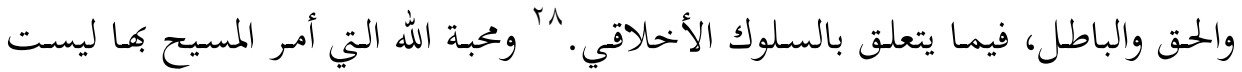

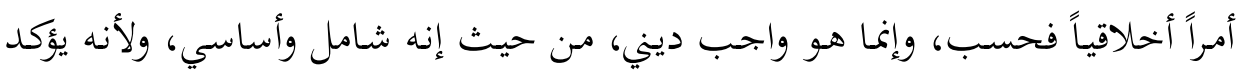

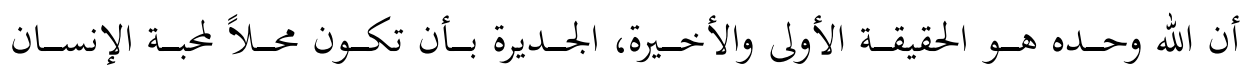
وخضوعه.

وأكد المسيح أن الله هو ذاته "الحقيقة"، وأن طبيعة هذه الحقيقة، هي حقيقة آمرة.

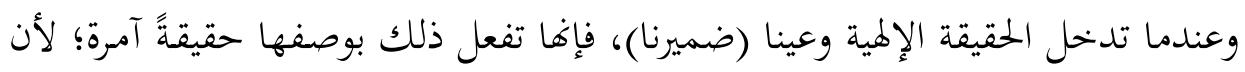

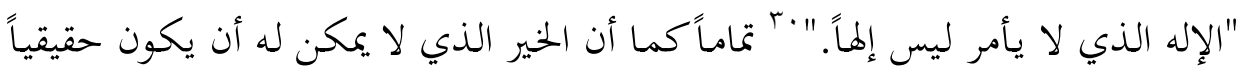

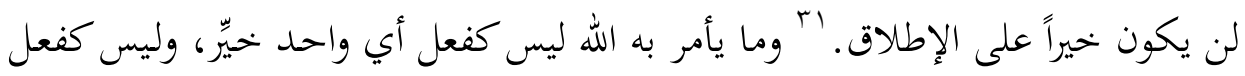

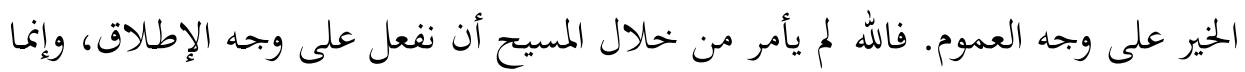
أن بنعل أنفسنا في علاقة محددة معه عزّ وجل.

هذه الوضعية تشير إلى نقل الإنسان من حالة عبادة الآهة الأخرى من قبل إسرائيل

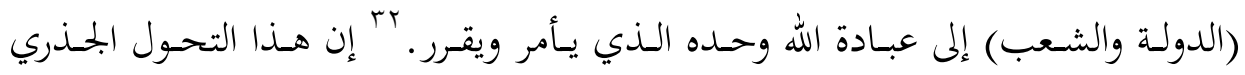

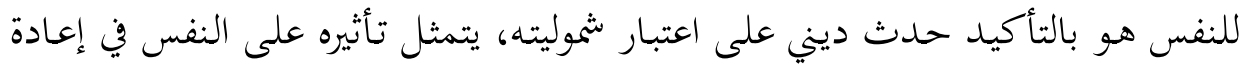

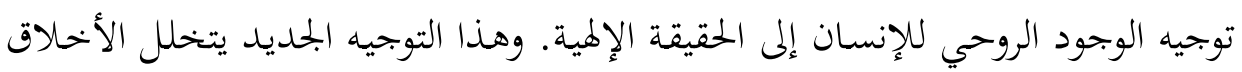

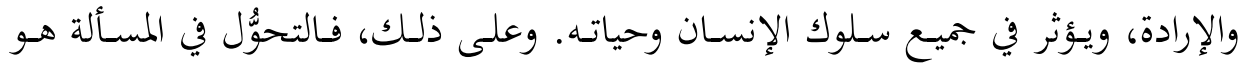

$$
\begin{aligned}
& \text { דr المرجع السابق، صrم . }
\end{aligned}
$$

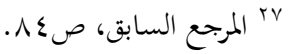

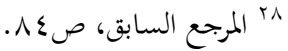

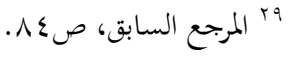

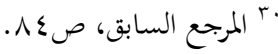

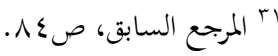

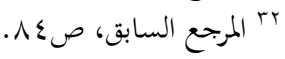


ظاهرة دينية واضحة. "َّ وأبعاد إعادة التوجيه للحياة هي مسألة أخلاقية، ولكنها ليست أسساً لجعل تلك الحياة مرغوبة، وإنما تكمن تلك الأسس في أسبقية المستوى الميتافيزيقي على المسـتوى الأخلاقي، وأسـبقية علـم القـيم (Axiology) علـى علــم الأخـالاق (Deontology)

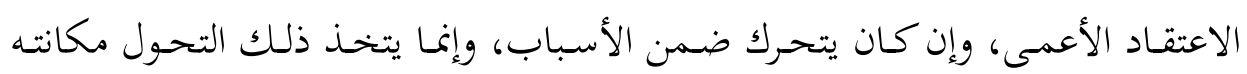

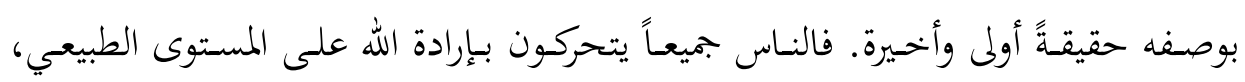

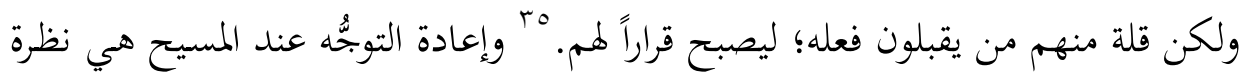

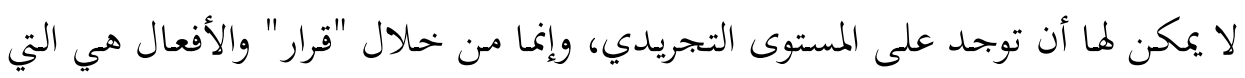

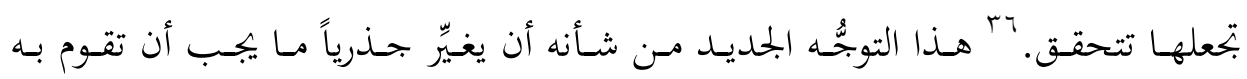
النفس، ويفتح النفس على تقرير القضايا من خلال مصدر واحد فقط، وهو الله. وهـذا الموقف ليس موقفـاً سـلبياً مـذعناً، ورلكنه دعـوة ديناميكيـة مـن الله للانتشـار

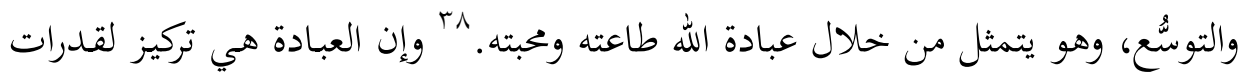

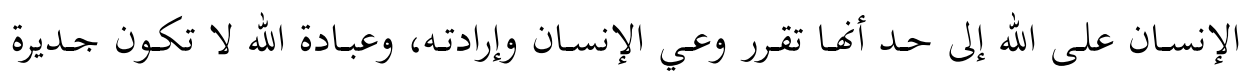

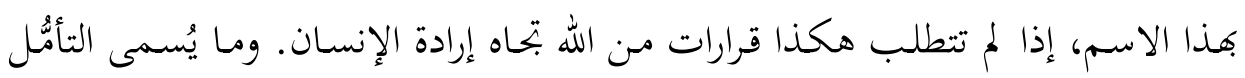

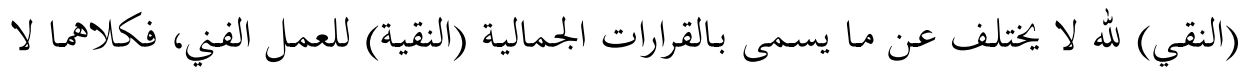

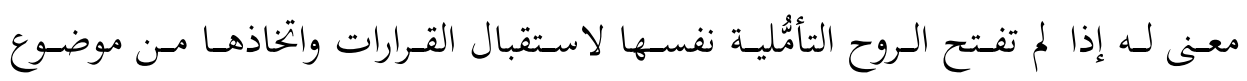

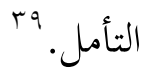

لذلك فالتحوّل الذاتي الذي دعا إليه المسيح، هو تحوّل ديني وأخلاقي في الوقت ذاته "أن تحب الله من كل قلبك، ومن كل روحك، ومن كل عقلك"، هذه هي الوصية الأولى هولى هولي

$$
\begin{aligned}
& \text { ك"rr المرجع السابق، صع م. }
\end{aligned}
$$

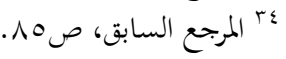

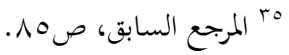

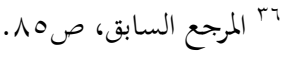

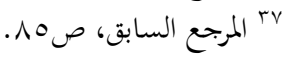

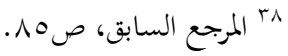

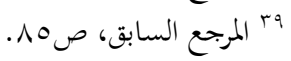


العظمى، فهي دينية بقدر مـا هي إعادة توجّه كامل نحو الله، وأخلاقية بقدر ما تكون

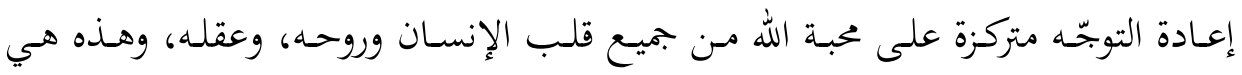

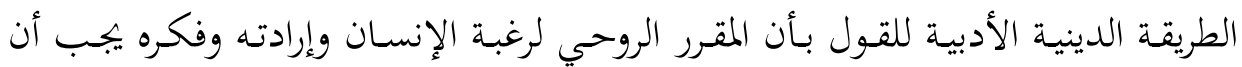

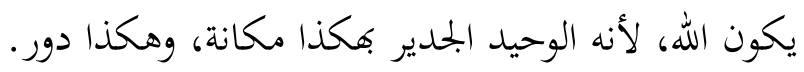

الحب ليس شيئاً آخر غير هذه الدعوة من الله؛ لتقرير الأخلاق والطاعة والاستجابة

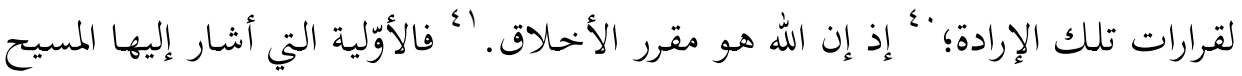

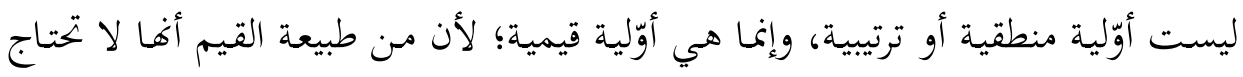

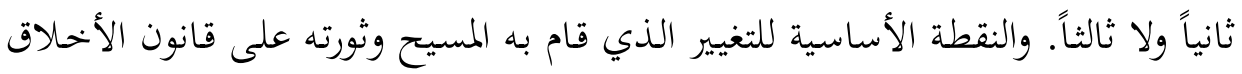

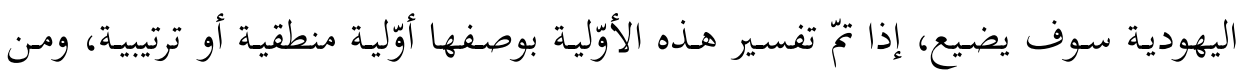

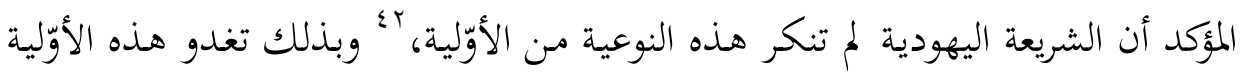

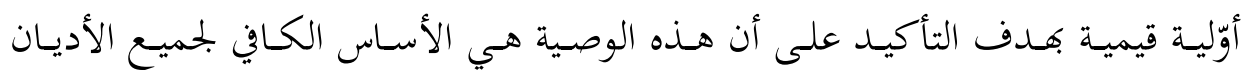

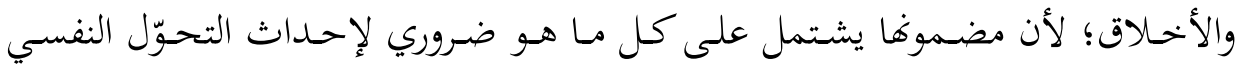

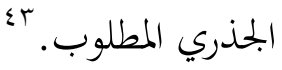

وعلى هذا الأساس يرى الفاروقي أن هذه الأوّلية لا تقبل إضافة وصية ثانية، ولذلك

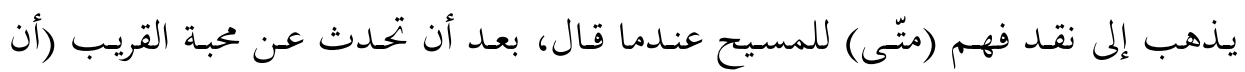
تحب قريبك كما تحب نفسك): "هاتين الوصيتين يتعلق الناموس كله والأنبياء"؛ إذ جاء:

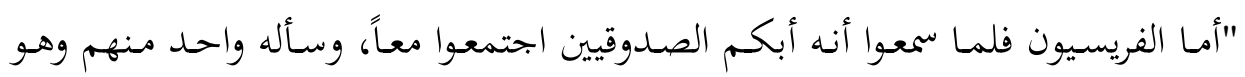

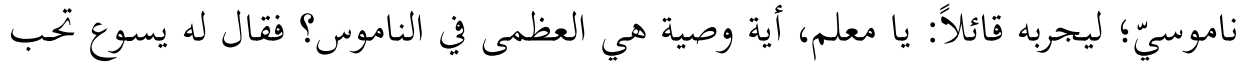

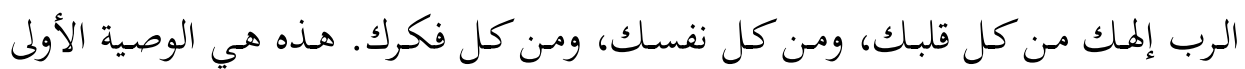

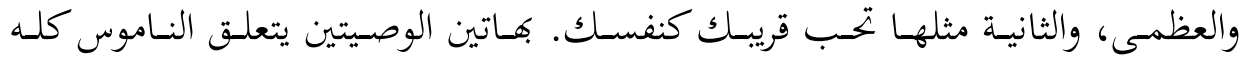

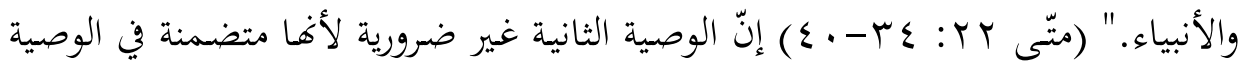

$$
\begin{aligned}
& \text { •؛ المرجع السابق، صهم. }
\end{aligned}
$$

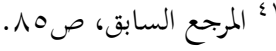

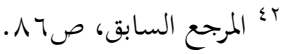

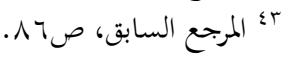




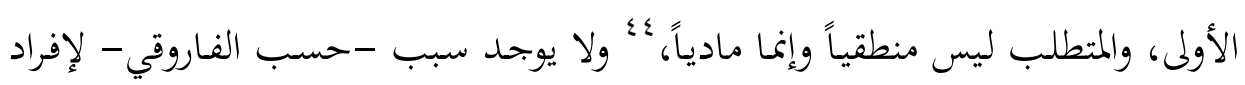

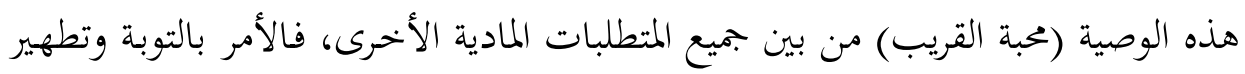

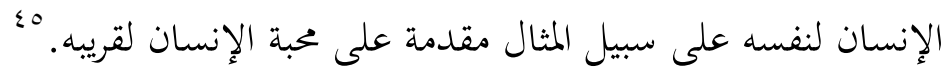

إن تعليق (متّى) بأن كل الشريعة والأنبياء جاءت من أجل هاتين الوصيتين يؤكد أنه

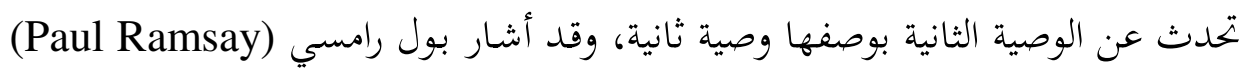

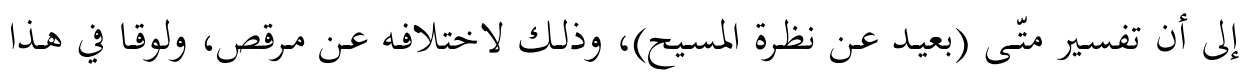

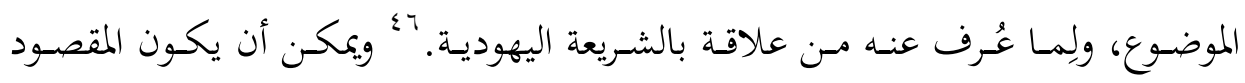

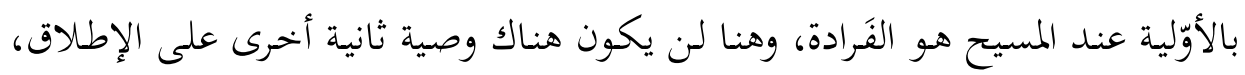
فمن قيمة الأوّلية أن تستبعد الحاجة إلى الثاني.

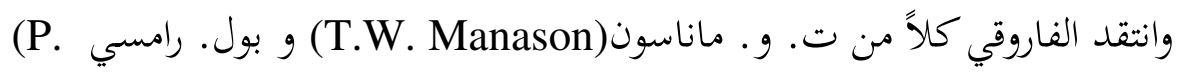
Ramsay)

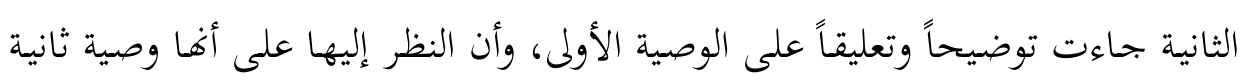

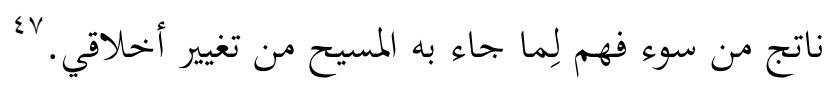

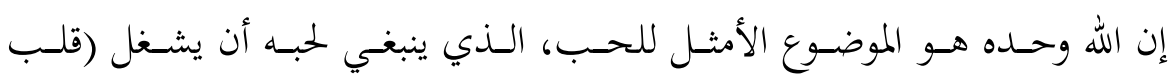

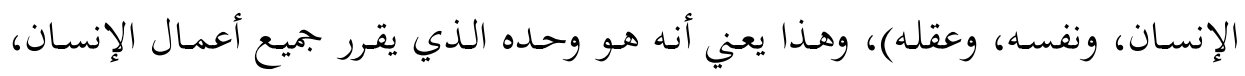

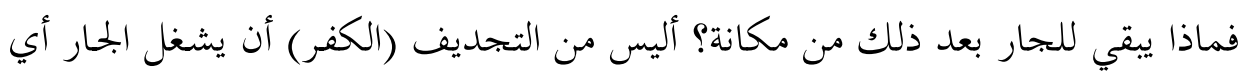

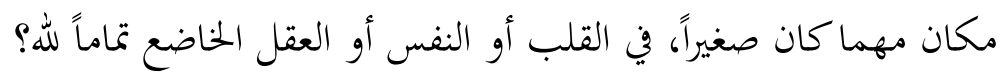
وانتقد الفاروقي قول (Manson) الذي يذهب إلى أن خبرة محبة الله تستتبع معرفة أن ذلك الحـب هو للإنسان؛ إذ يرى الناس من خهال عيون الله. وأن يراهم بعيون الله الله

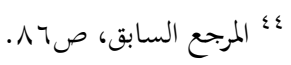

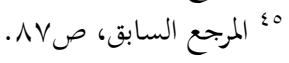

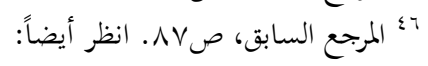

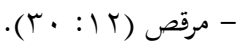

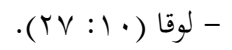

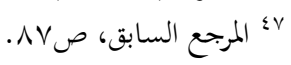


يعني أن يحبهم. ورأى الفاروقي في هذا الرأي خلطاً في الأوامر بين الوصية الأولى والوصية

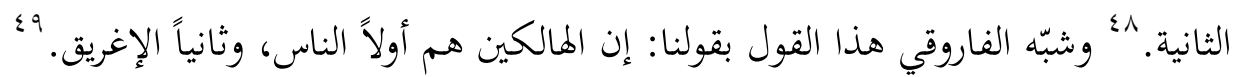

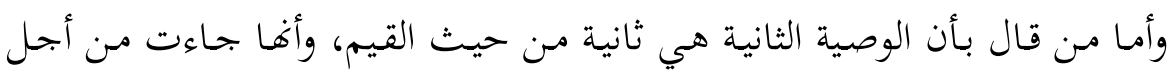

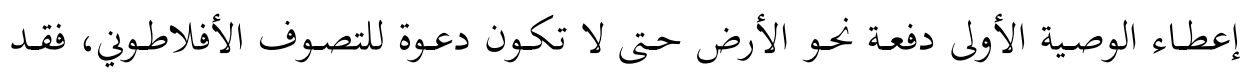

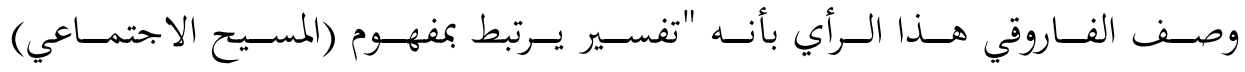

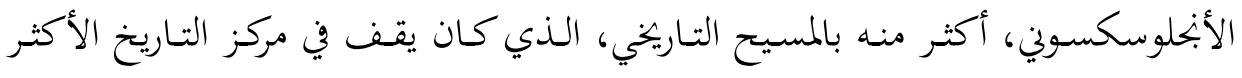
عنصرية واحتضاراً."둔

\section{جدلية الأخلاق الجديدة}

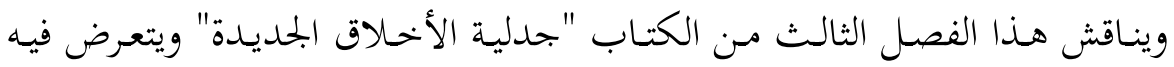

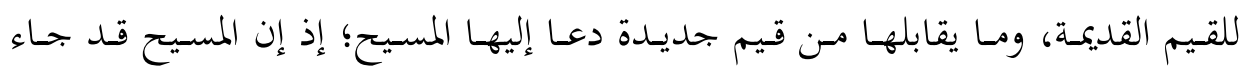

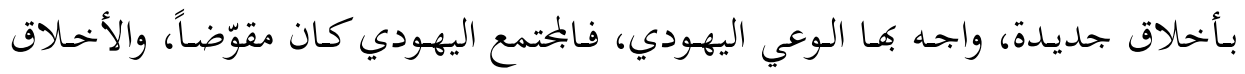

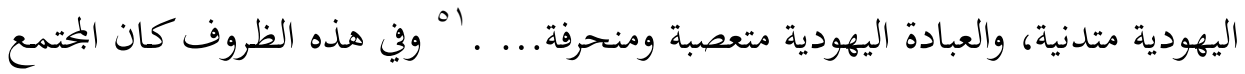

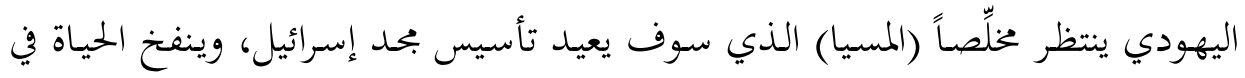

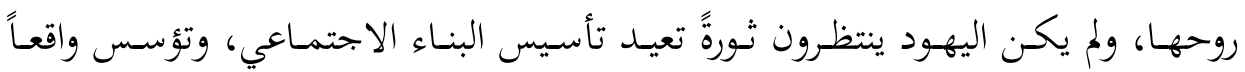

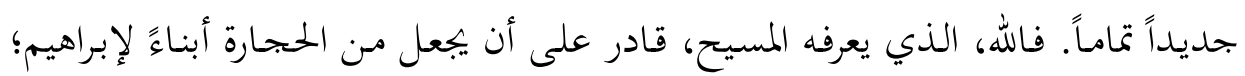

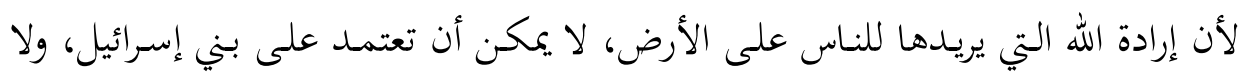

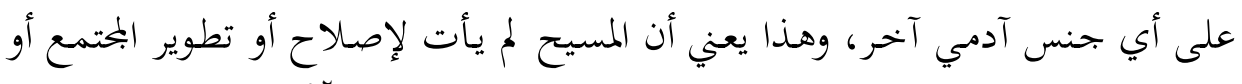

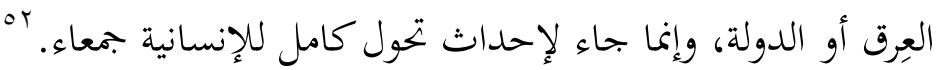

لقد أراد المسيح أن يأت بميلاد كامل وجديد للعالم، ولذلك أخبر المسيح اليهود بأنه (لا يرى ملكوت السماء) بينهم. بو وبهذا رفض المسيح فكرة اختيار اليهود، فبالنسبة له آله

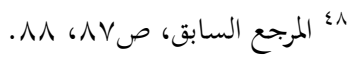

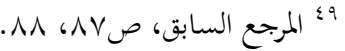

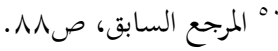

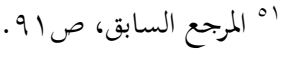

$$
\begin{aligned}
& \text { ror المرجع السابق، صل } 9 . \\
& \text { ror المرجع السابق، ص19 الساتق } 91 .
\end{aligned}
$$




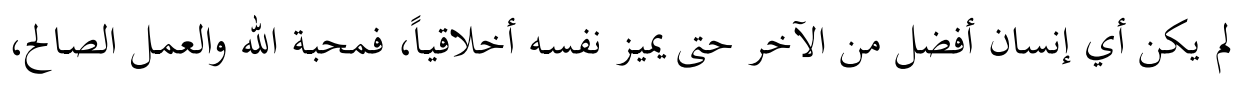

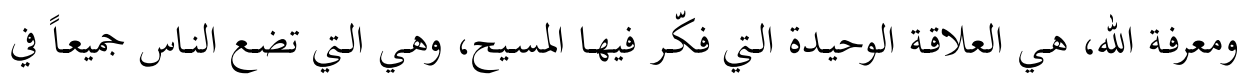

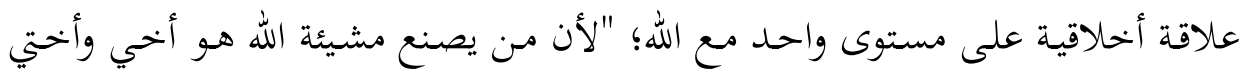

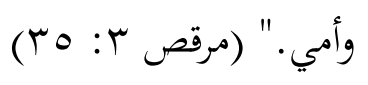

والله في نظـر المسـيح لـيس إلـاً لليهـود وحـدهم أو لإبـراهيم أو يعقـوب أو إسـحق

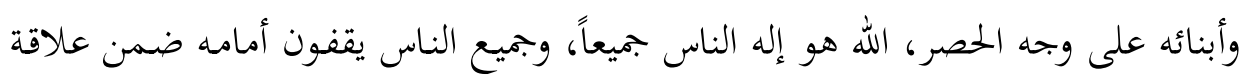

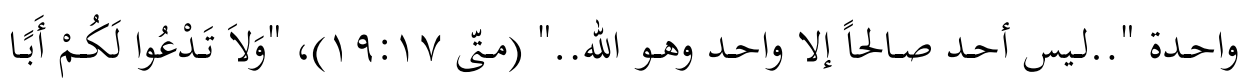

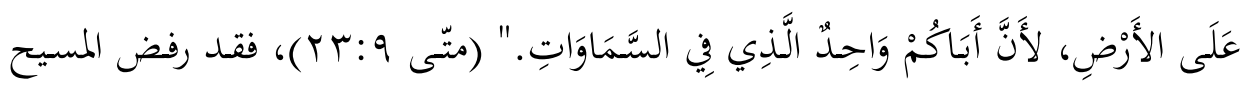

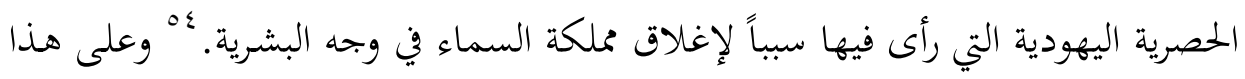

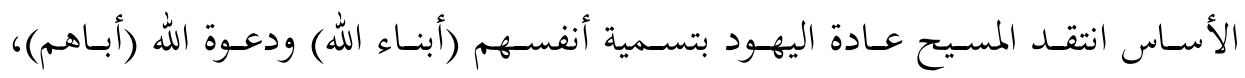
وأخبرهم بأنه إذا كان هناك أحد جدير بأن يكون أباهم فهو الشيطان، فالمسيح نفى أن أن أنساء يكون لليهود علاقة أبوية مع الله.

وانتقد الفاروقي إظهار (متّى) المسيحَ معلماً للشرائع اليهودية، كما ترسّخت خلال

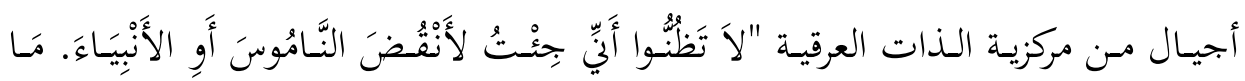

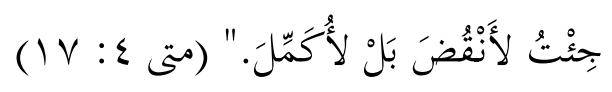

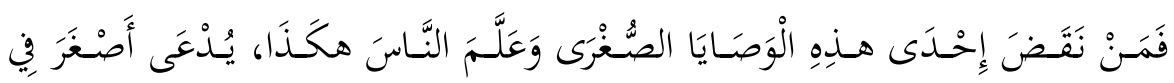

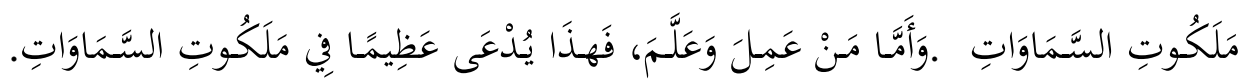
(متّى ع: 9 (1)، كما جعل متّى رسالة المسيح مصصورة في قبائل إسرائيل وخرافها الضالة.

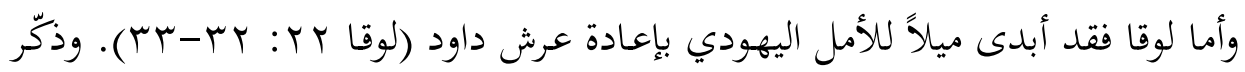

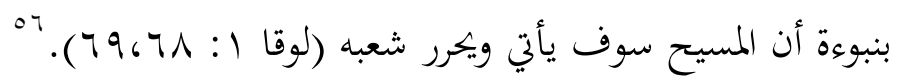

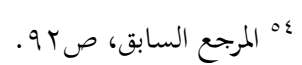

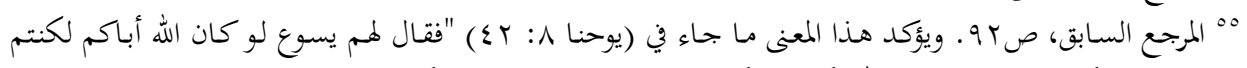

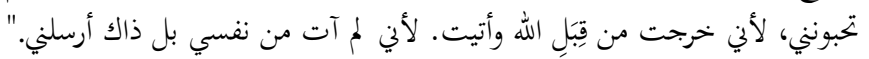
rه المرجع السابق، صبوني، لأي صرحت من 
لقد حطّم المسيح أسس الأخلاق اليهودية القائمة على (الإقصائية العرقية)، وأخبر

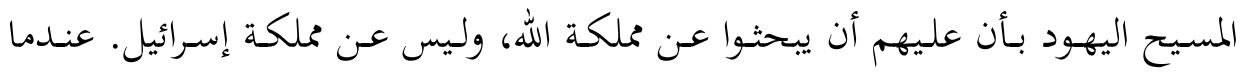

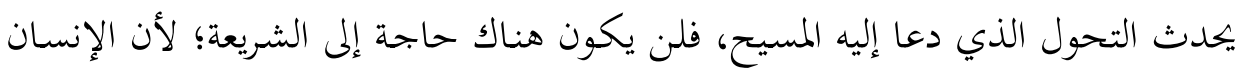

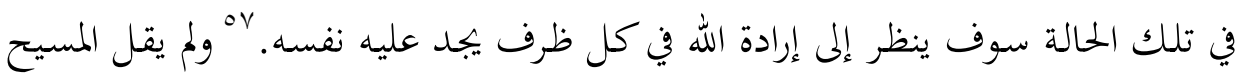

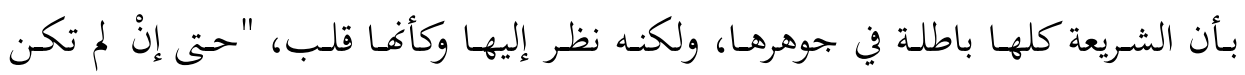

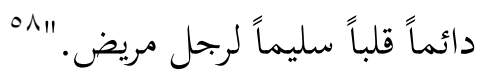

\section{القيم القديمة، والقيم الجديدة:}

تناول المؤلف في الفصل الثالث من الكتاب موضوع القيم القديمة والقيم الجديدة، وسعى إلى إبراز تباين القيمي في الروايات المسيحية عن المسيح المئئهن.

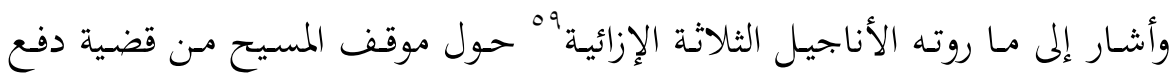

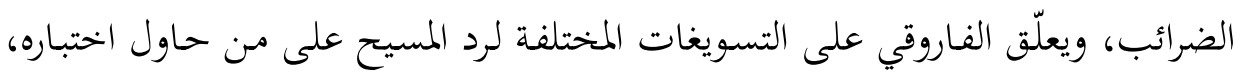

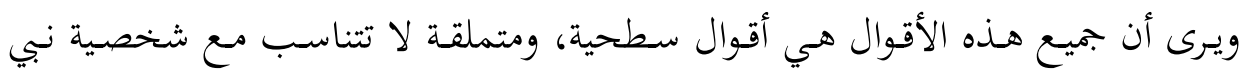

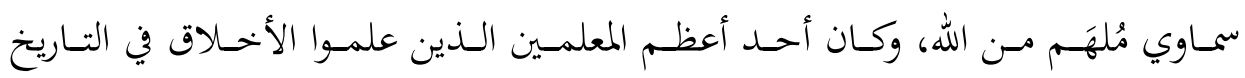
الإنساني."

لقد جـاءت أخلاق المسيح؛ لتكون ثورة على النظرة اليهودية، التي رأت أن المحبة

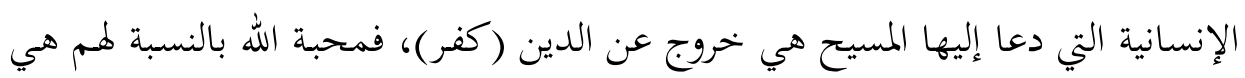

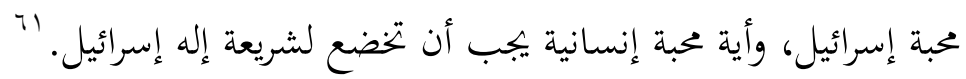
مثّلـت قضـية عمل الخـير يوم السبت علامـة فارقة بـين التعاليم اليهوديـة وتعـاليم

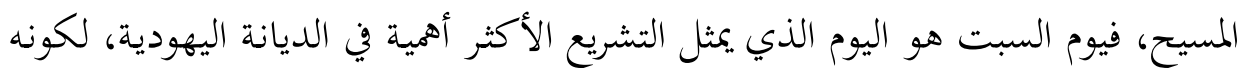

$$
\begin{aligned}
& \text { لم المرجع السابق، صع } 9 . \\
& \text { ه م المرجع السابق، صع و } 9 .
\end{aligned}
$$

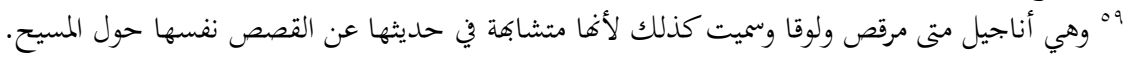

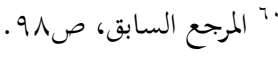

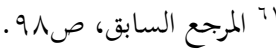


يمثل العلاقة الخاصـة بيـهـم وبـين الله. بَّ وقـد جـاء في التعـاليم الربانيـة اليهوديـة أنه "إذا حافظت كل إسرائيل على سبتين (أو سبت واحد) بكل تفاصيله، فإن إسرائيل سوف

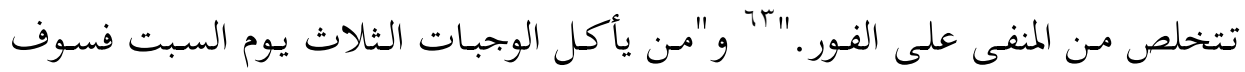

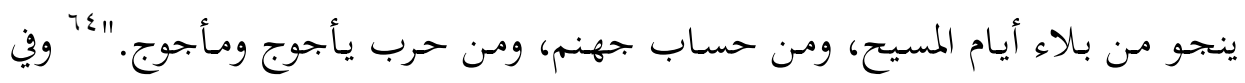
حين كان الفريسيون يدعمون قدسية يوم السبت كان المسيح يدعم قدسية عمل الخير.

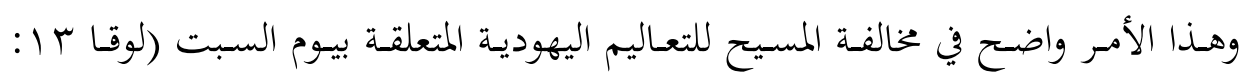
10. (1)

لقد سعت اليهودية إلى إخضاع مفهوم الخير لمصلحة بقاء المجتمع، في حين سعى

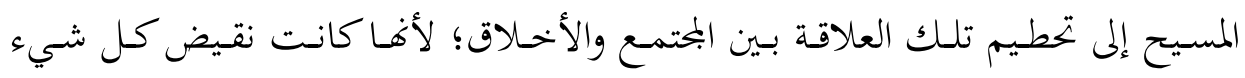
يسعى إليه، فالخير والقواعد الأخلاقية كانت هي الغاية العظمى بالنسبة إليه، وهي مسألة حاسمة؛ لأهما تتضمن محبة الله للأخحلاق.

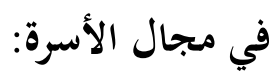

سعى الفاروقي إلى إظهار التباين الكبير بين الأخحلاق اليهودية (التي انتقد مرجعياها

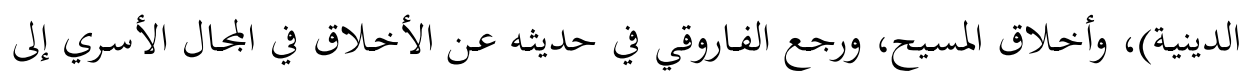

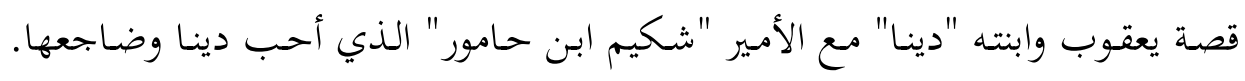
ويذكر سفر التكوين كيف أن يعقوب قد اشترط على شكيم أن يختتن هو وقومهه، وأن

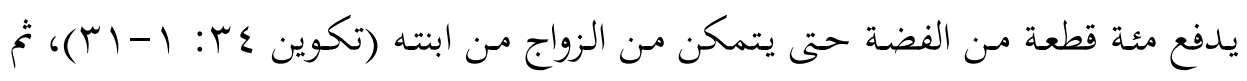

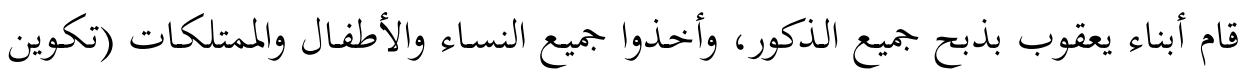

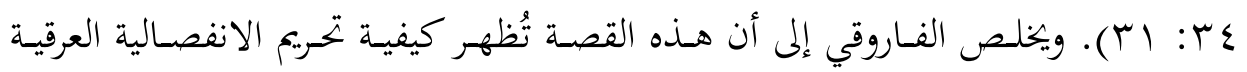

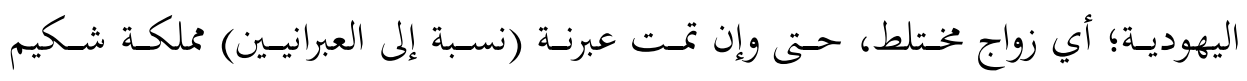

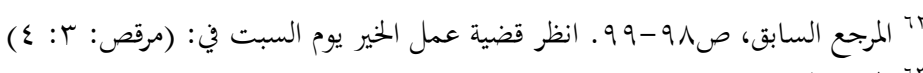

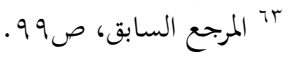

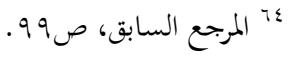

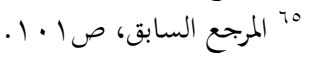

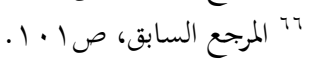


كلها. لَّ كما رأى الفاروقي في هذه القصة تأكيداً على الانفصالية العرقية الحصرية التي

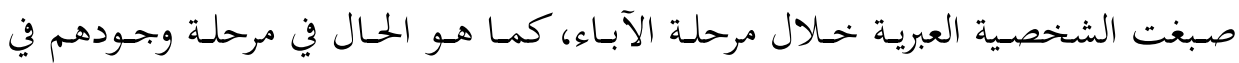

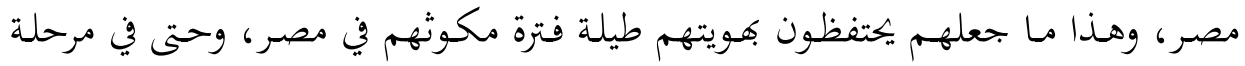

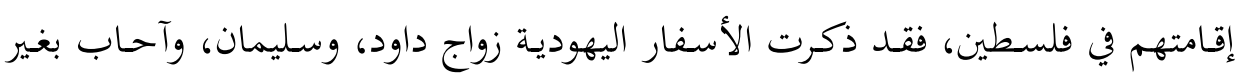

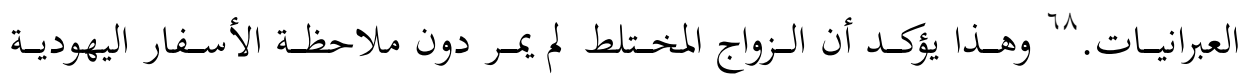
وإدانتها له.

وعلى المستوى الشخصي فإن المحالات السياسية والاجتماعية والأسرية تعطي أفقاً

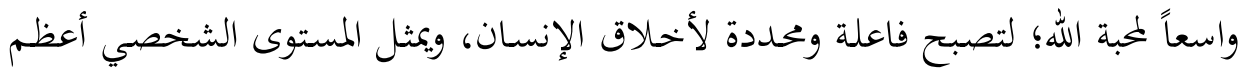

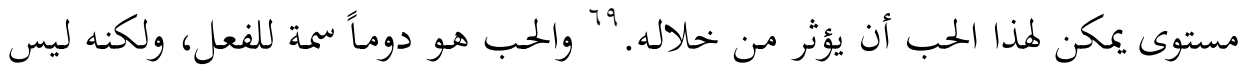

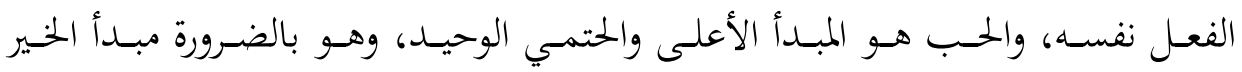

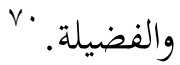

\section{أخلاق المسيح والشرعية المسيحية:}

نظر الفاروقي إلى أخلاق المسيح على أها تأسيس أصيل للتحرر من الشريعة على الثل

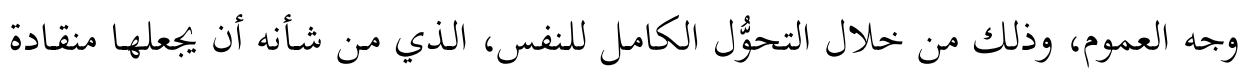

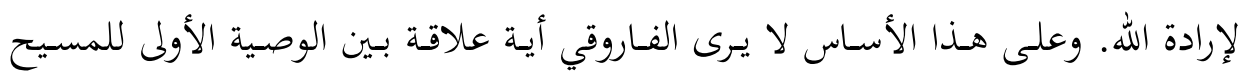
(محبة الله) و"شريعة المسيح"، ويرى أن هذا المصطلح الأخير لم يتم توضيحه أبداً.

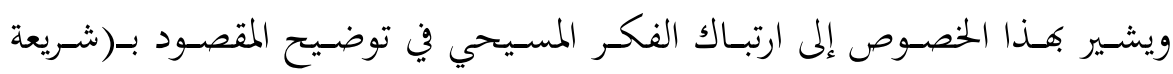

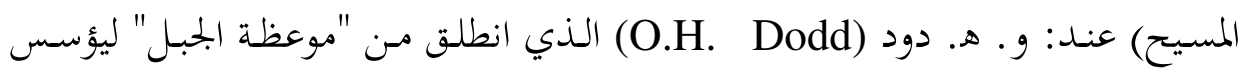

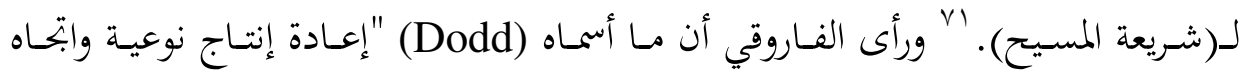

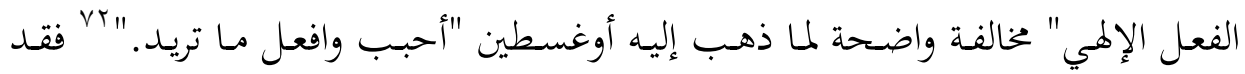

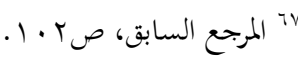

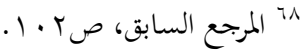

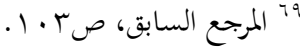

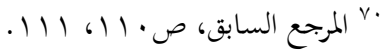

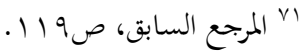

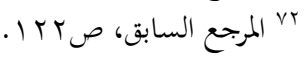


ذهب (Dodd) إلى أن المسيح نفسه قد وضع عدداً كبيراً مـ المبادئ الأخلاقية بصيغة

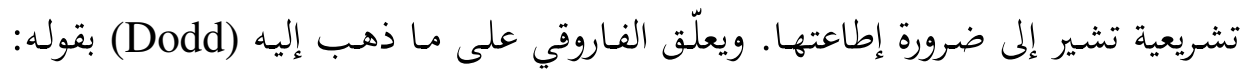

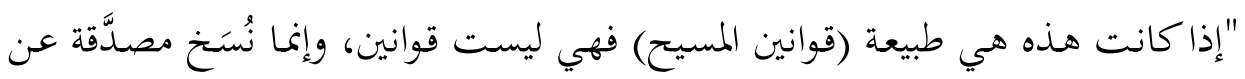

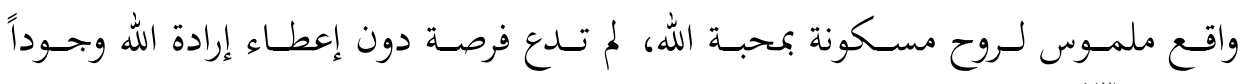
حقيقياً.

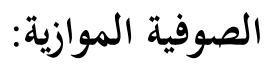

يناقش الفاروقي في بداية هذا الفصل المقولة التي تذهب إلى أن التصوف في كل من

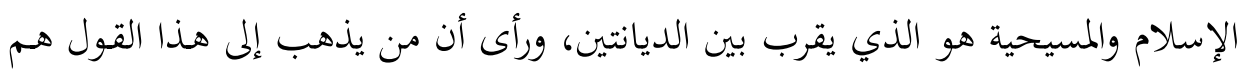

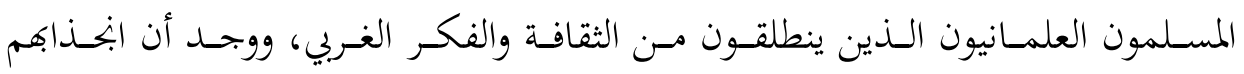

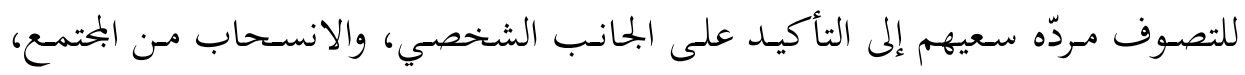

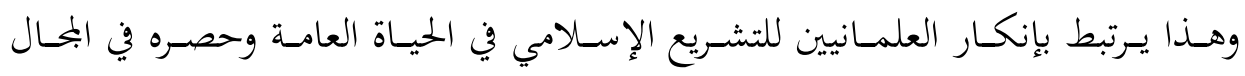

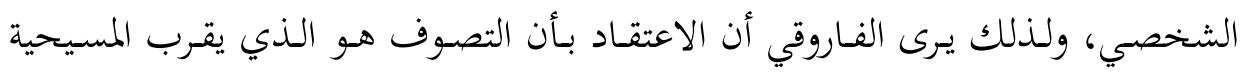

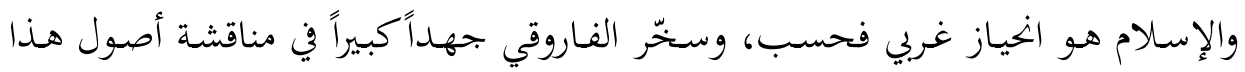

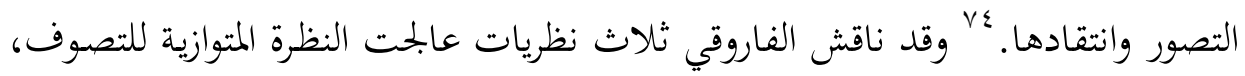
وأخلاق المسيح على النحو الآتي: أولاً: ما ذهب اليه عدد من الدارسين المسيحيين والعلمانيين من جهة، والإسلاميين

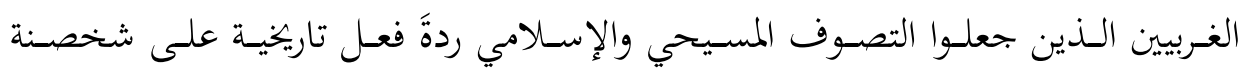

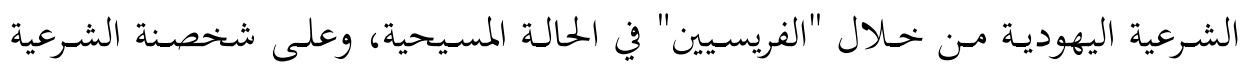

$$
\text { الإسلامية من خلال "الفقهاء" في الحالة الإسلامية. }
$$

ثانياً: رأي لويس ماسنيون، الذي يؤيده أغلب الدارسين المسلمين؛ إذ يرى أن أصل التصـوف كـان في زهـــ النبي والصسحابة، وأنسه كـان تطوراً داخـل الإسـلام، ولـيس تـأثراً Vo بالعناصر الخارجية.

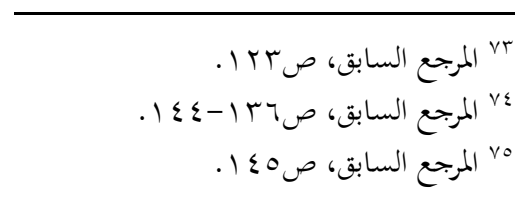


ثالثاً: إن التصوف هو الإسلام نفسه، وإنّ المتصوف الأول كان هو النبي محمد وإنّ كتاب التصوف الأول كان هو القرآن. وقد انتقد الفاروقي هذه الابحاهات الثلاثة في

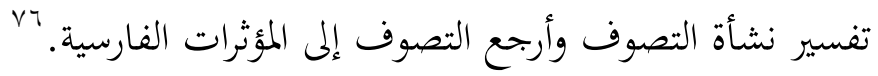

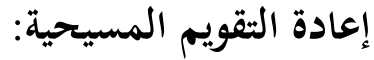

هـذا العنوان القسـم الثاني مـن الدراسة، والذي يشتمل على ثلاثة فصول، تنـاول

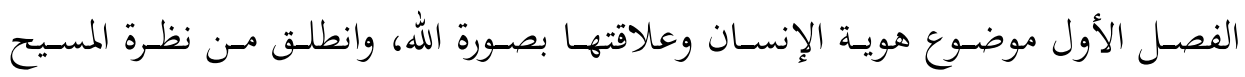

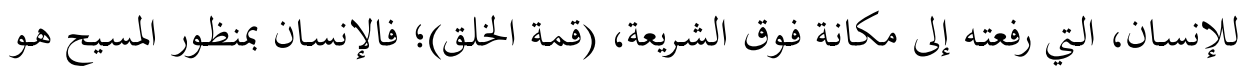

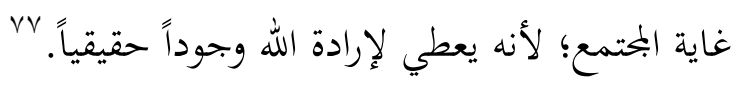

\section{في المسيحية الهلينية: الإنسانية}

ينطلق الفـاروقي تحت هذا العنوان من مقدمـة ذهب فيها إلى أن قيمة الإنسـان في

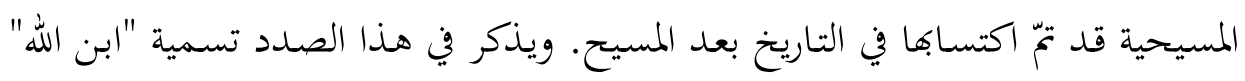
التي استعملها لوقا في حديثه عن آدم؛ إذ رأى الفاروقي أن لوقا قد أعطى آدم والبشرية

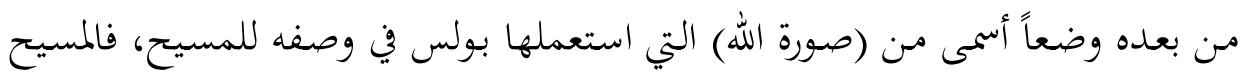

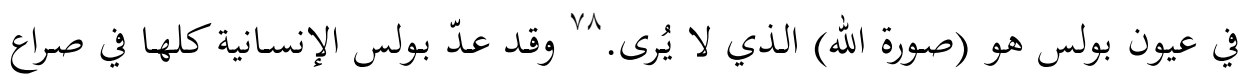

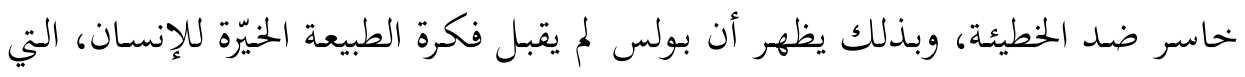

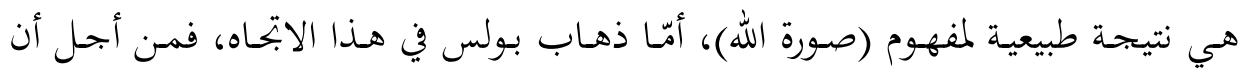

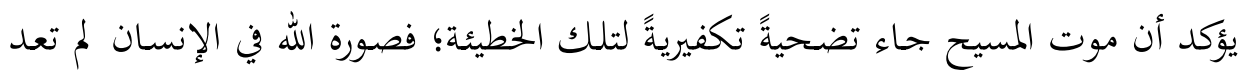
موجودة بالنسبة لبولس.

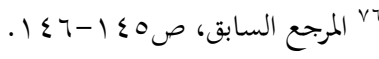

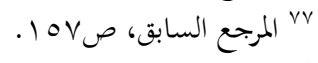

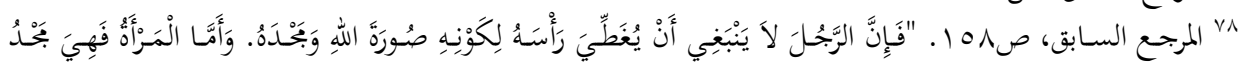

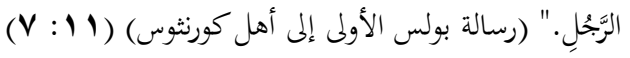




\section{مسيحية ما قبل الإصلاح، رفض الضرورة الإنسانية للإنسان va}

أضـاف القـديس أوغسطين مَلَكـة الحـب إلى كل مـن مَلَكتي التـذكر والمعرفة، اللتـين رأى فيهما أفلاطون المكونين للصورة الإلهية في الإنسان. أما الروح فهي التي تعطي هذه القـوى فعاليتها، وهـي "الصـورة والشََّبه" الـذي على أساسـه جعـل الإنسـان فـوق جميع

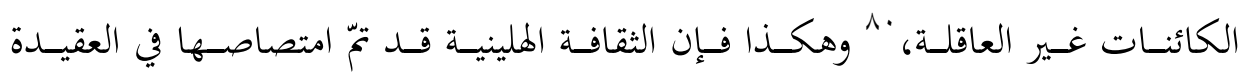

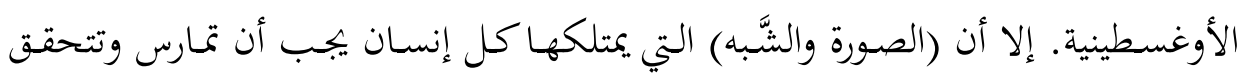
بالشكل الصحيح، وهذا ما يعطي (الصورة) بعدها الأخلاقي، وجعل قيمة الشَّبَه (الشَّبه الإلهي) قيمة حيادية وملكة ضرورية للإنسان، ولكن يبقى السؤال: كيف يمكن لقيمة (الثّبه الإلهي) أن تضيع في استعمالها الإنسـاني؟ وللوصول إلى إجحابـة عن هـذا السؤال حاول أوغسطين أن يفرّق بـين تعبير (كصورتنا أو شَبَهِنا) وكنوعـه (نوع الإلهه). فسِفر

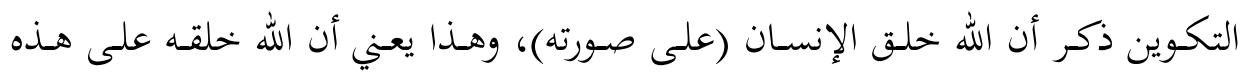
الصورة حتى يتمكن من الرجوع إلى الله.

ويرى الفاروقي أن القديس أوغسطين لم يفهم المقصود بالعبارة التوراتية؛ نظراً لوعيه

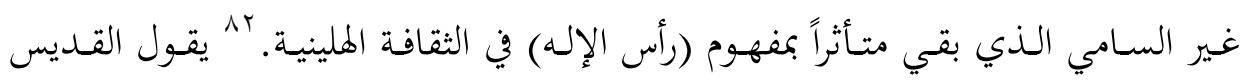

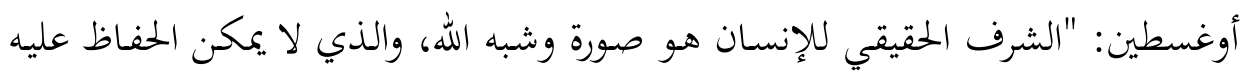

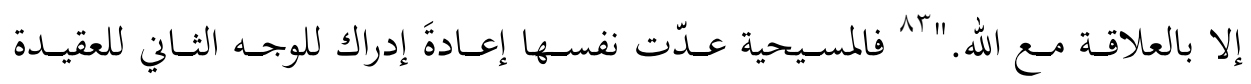

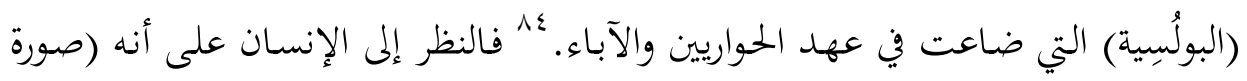

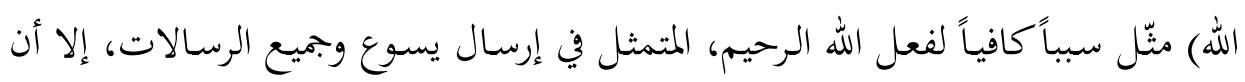
الفاروقي لاحظ أنه من غير الممكن لغير المسيحي أن يقول إنه يملك (صورة الله) فيه، وبما

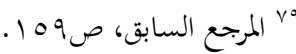

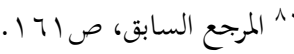

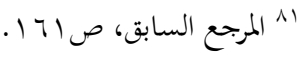

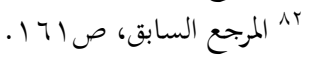

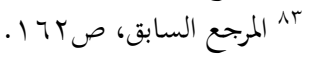

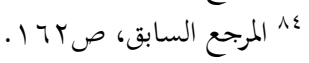


أن هذه الصورة ضرورية لتحقيق الإنسانية، فإن ذلك يؤدي إلى القول بأن غير المسيحي ليس إنساناً.

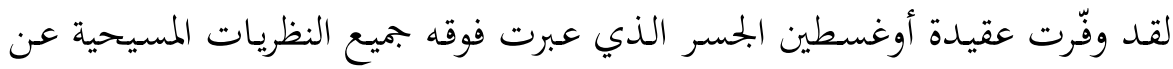

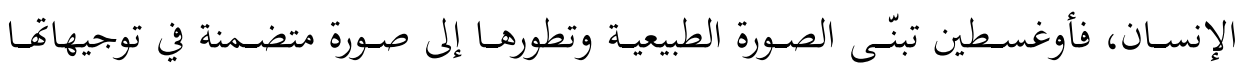

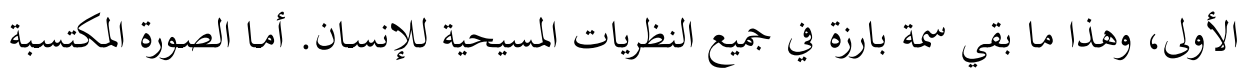

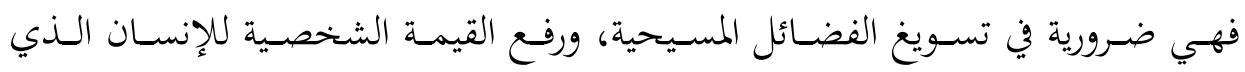

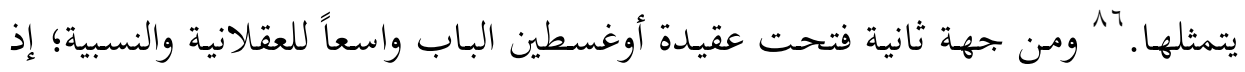

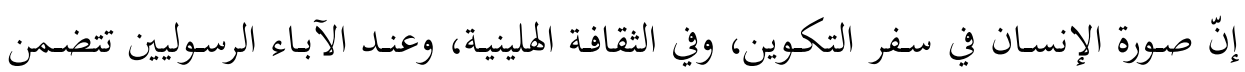
القول بأن صورة الله في الإنسان تعني أنه مكرَّم بحد ذاته.

وفي حديث الفاروقي عن تأثير الفكر الإسلامي في اللاهوت المسيحي، يذهب إلى أن هذا التأثير كان مـ خهلال النظر إلى الإنسان بوصفه كائناً عقلانياً قابلاً للتعليم...

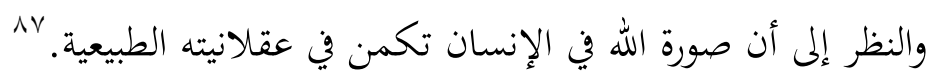

\section{في الإصلاح: إصلاح همجية الإنسان}

سعى مـارتن لوثر إلى تحرير المسيحية مـن سـلطة روما وكنيستها، وإلى القول بـأن

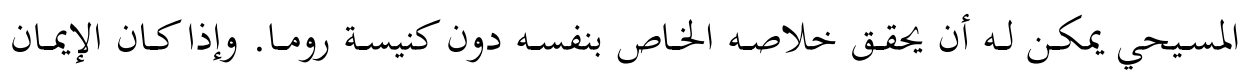

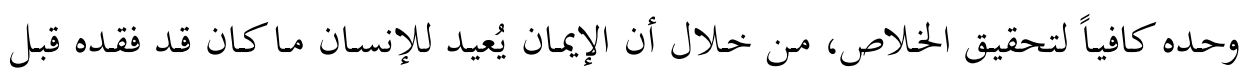

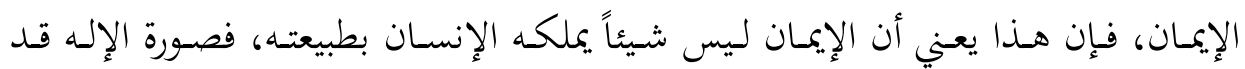

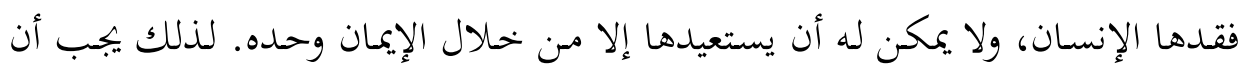

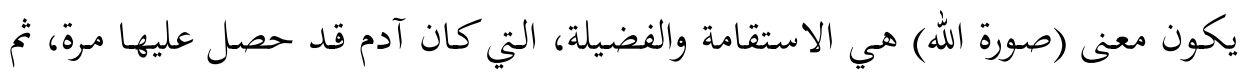

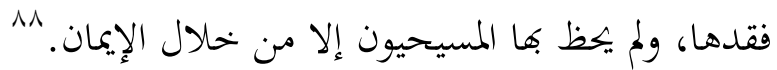




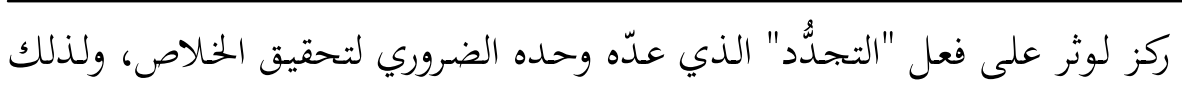

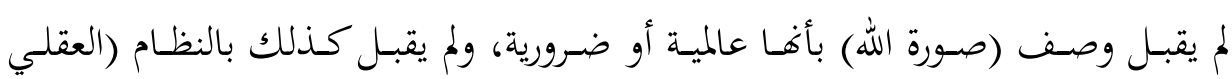
الطبيعي).

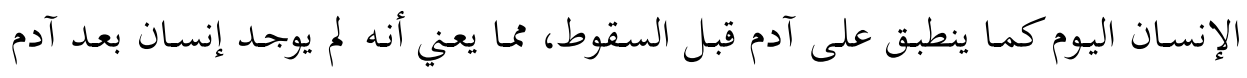

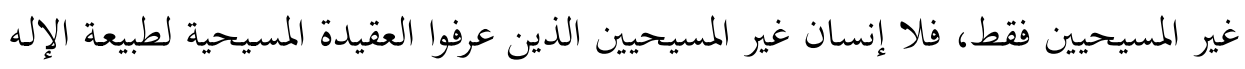

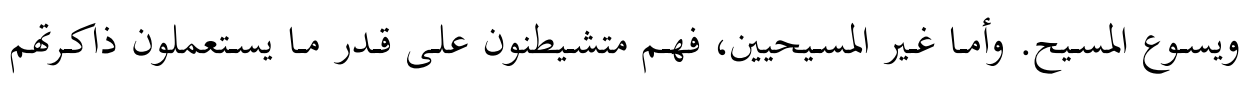
وإراداهم وعقولم. وبست.

ويذهب لوثر إلى أن ظروف آدم الطبيعية قد كانت أسمى مما آلت إليه بعد ذلك، ألكا.

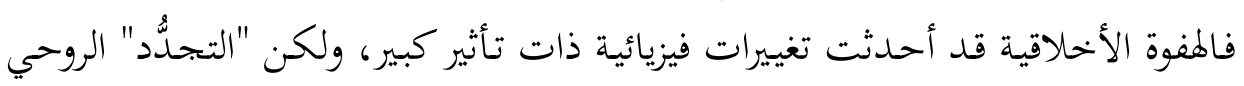
لم يحدث أياً من تلك التغيرات على الإطلاق.

\section{في المسيحية المعاصرة: أوهام غير العقلانيين}

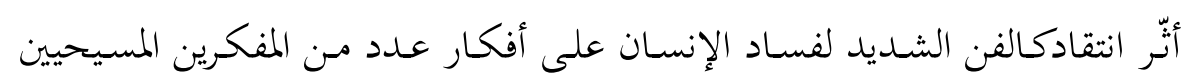

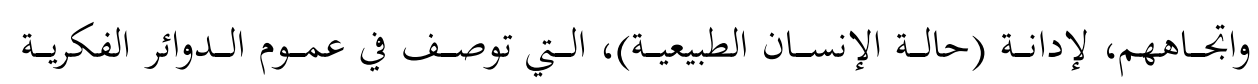
البروتستانتية بـ (الخطيئة).

ويمثل الفيلسـوف الوجـودي سـيرن كيركجـارد "Soren Kierkegaard" صـورة

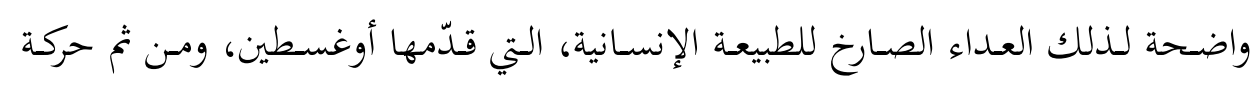

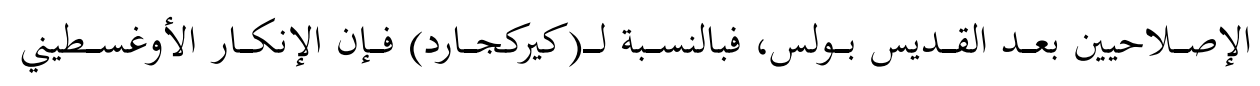

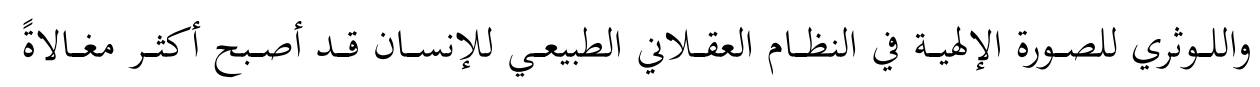

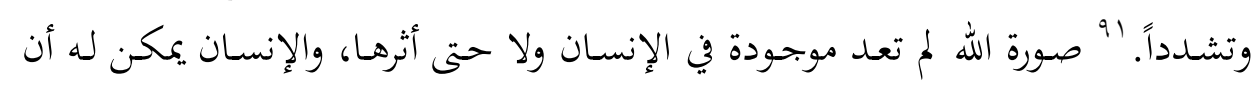

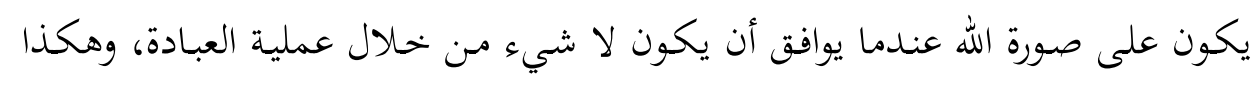

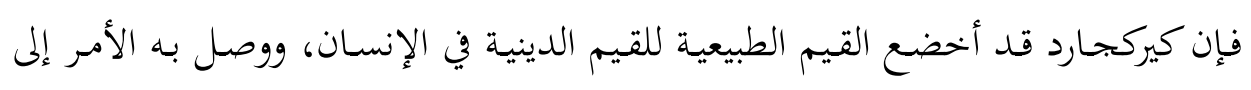

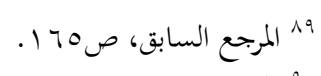

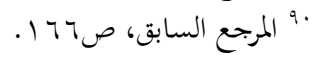

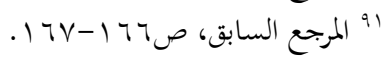


إنكار (الصورة الطبيعية)، ليس بوصفه قيمة فقط بل (بوصفها وجوداً). بو إن الوعي

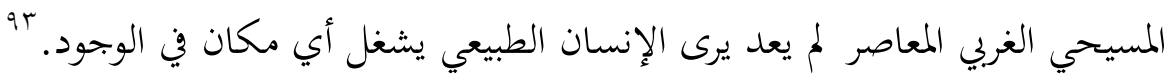
ويتناول الفاروقي أبرز من تحدث عن مسألة طبيعة الإنسان من المفكرين المسيحيين

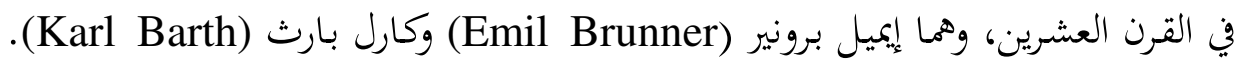

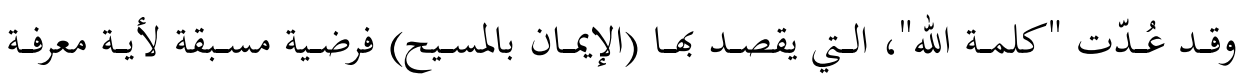

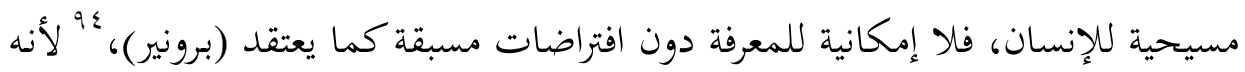

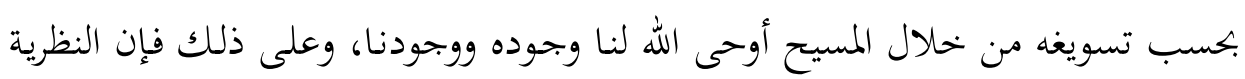

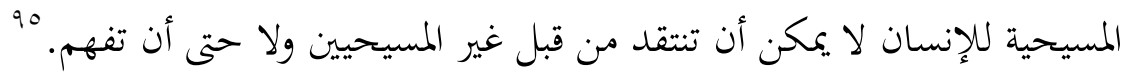

\section{ماذا على الإنسان أن يكون؟}

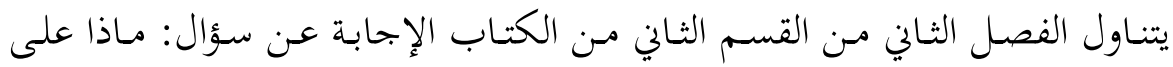

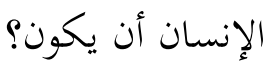

وتحت موضوع الخطيئة والخلاص، يذهب الفاروقي إلى أن البدهية القطعية في الوعي

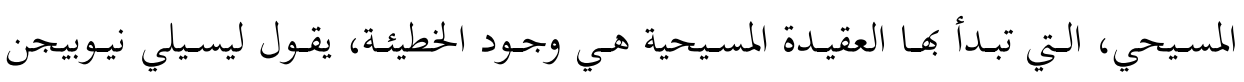

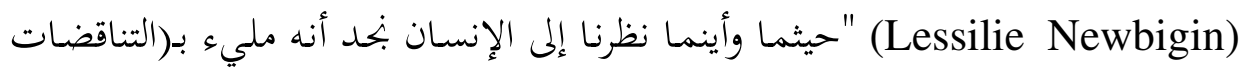

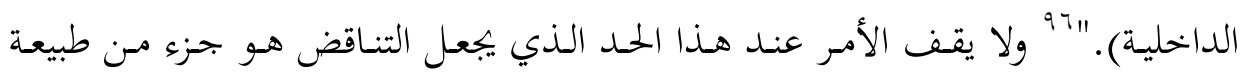

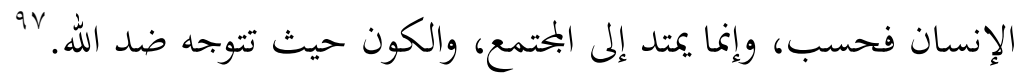

التأكيد على وجود الخطيئة (كون الخطيئة) لا يؤكد الحقيقة الإمبيريقية (التجريبية)

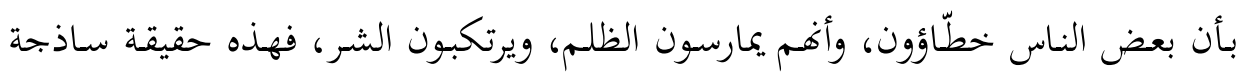

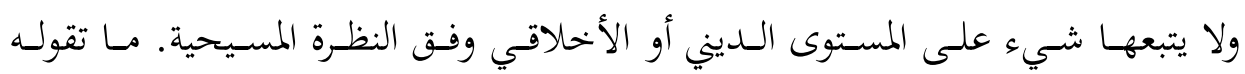

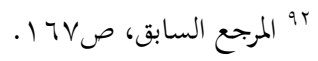

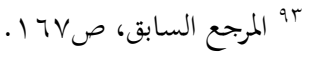

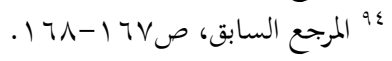

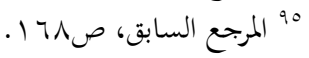

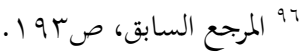

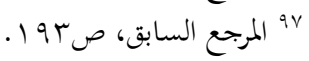




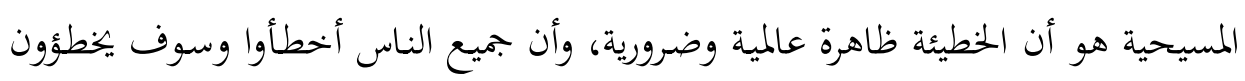

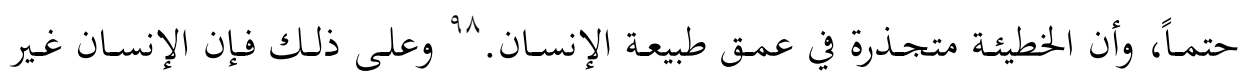

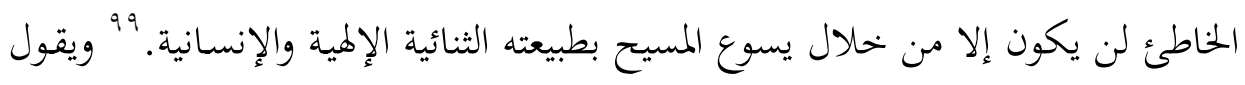

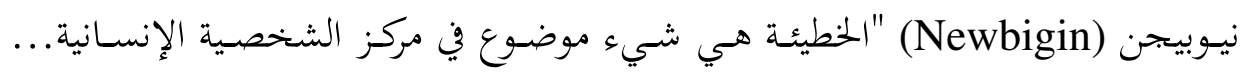

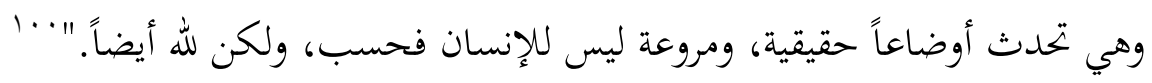

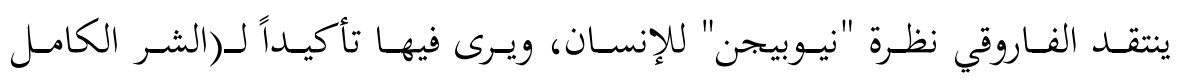

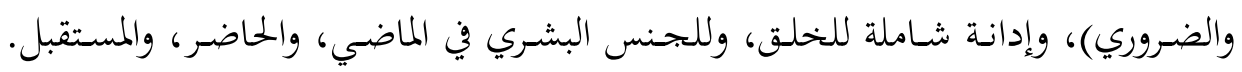

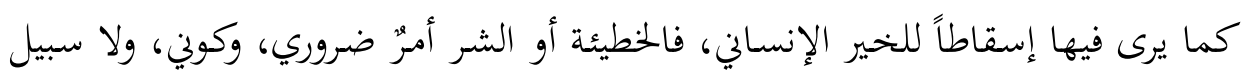

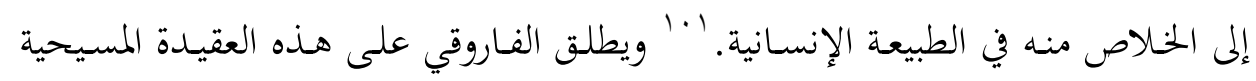

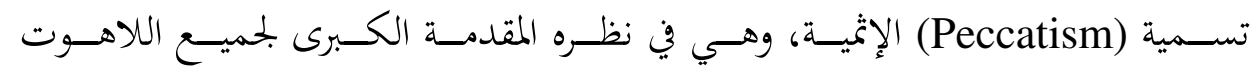

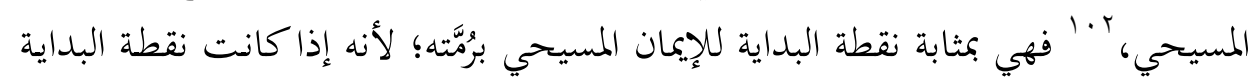

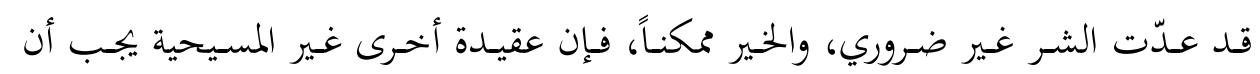

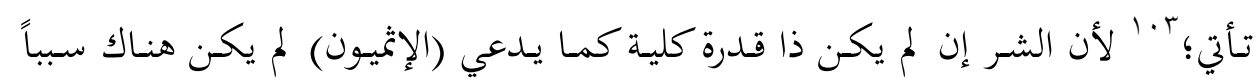

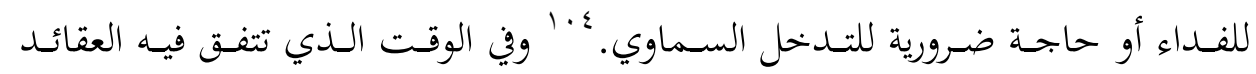

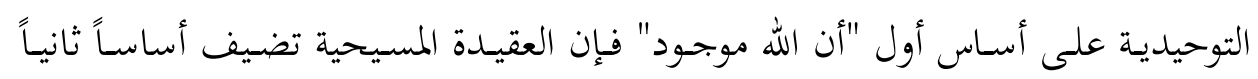

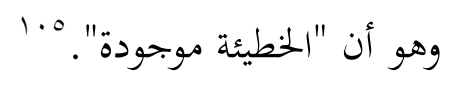

ويذهب الفـاروقي إلى أن المسيحية لا ترضى ولا تستطيع أن ترضى ببدهية "أن الله

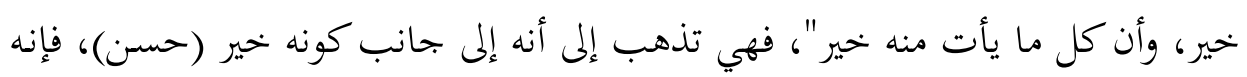

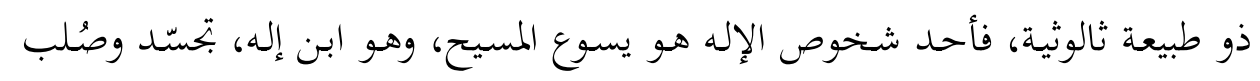

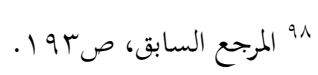

999 المرجع السابق، صع صع 19.

ل..' المرجع السابق، صغ صغ 19.

1. المرجع السابق، صغ صغ 19.

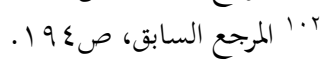

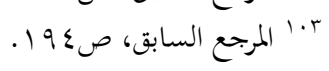

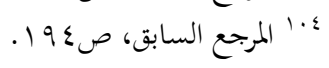

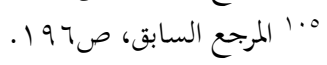




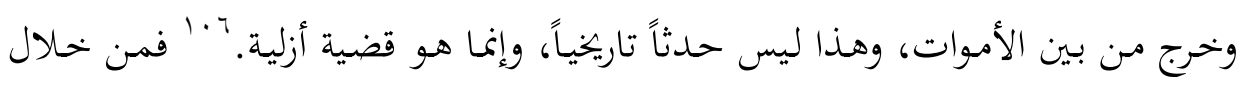

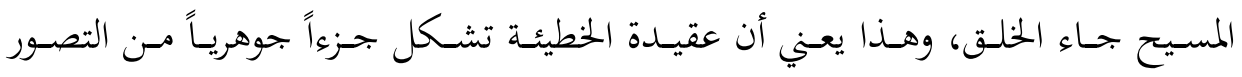
المسيحي للإله.

ويذهب الفـاروقي إلى أن العلاقة بين الإله والشّر قد جاءت مـ الديانة المانوية أو

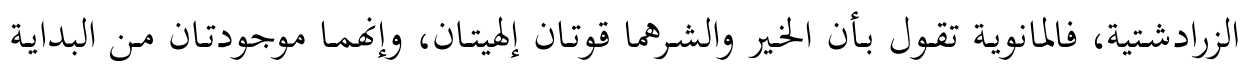

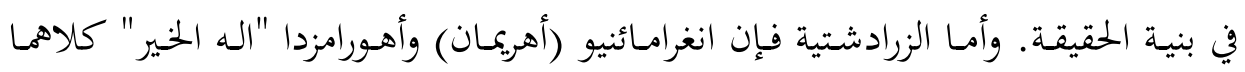

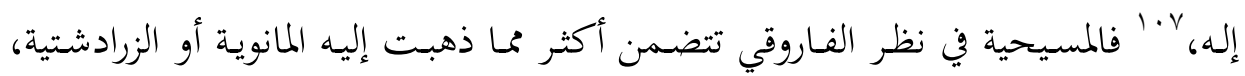

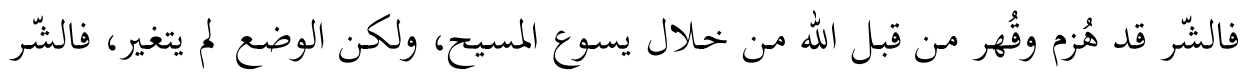

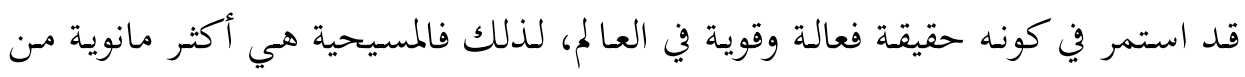

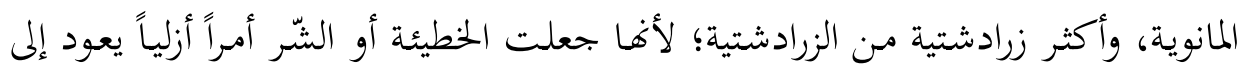

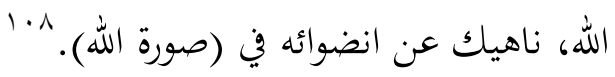

\section{الخلفية اليهودية:}

يعود الفاروقي إلى التاريخ اليهودي؛ ليبحث عن أصول فكرة الخطيئة والشّر ، فيرى

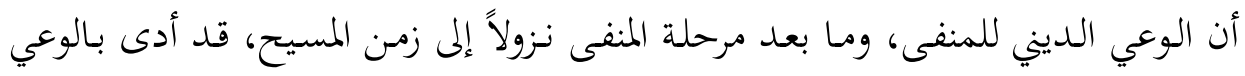

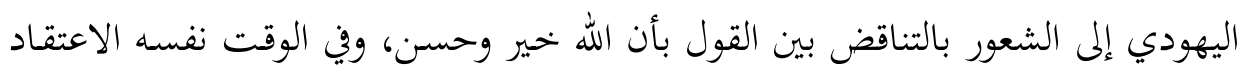

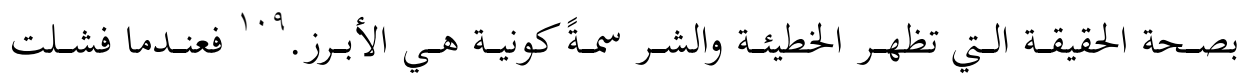

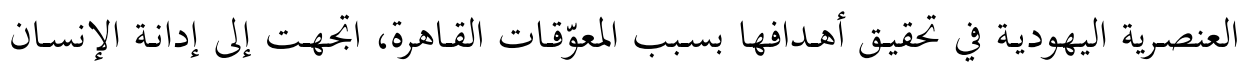

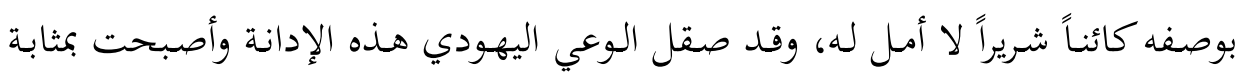

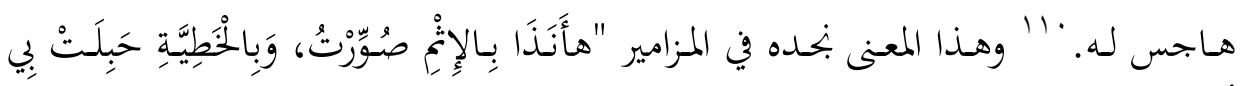

$$
\text { أُمِّي" (0: }
$$


وعلى الرغم من أن هذا المعنى ليس مطابقاً لنظرية "الإثمية" المسيحية، ولكنه يمثل

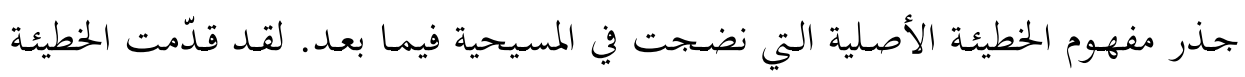

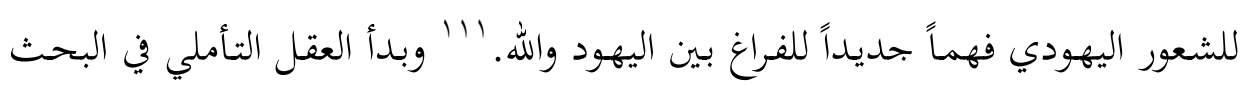

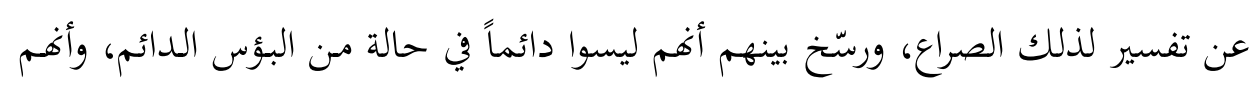

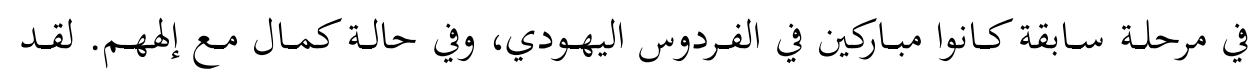

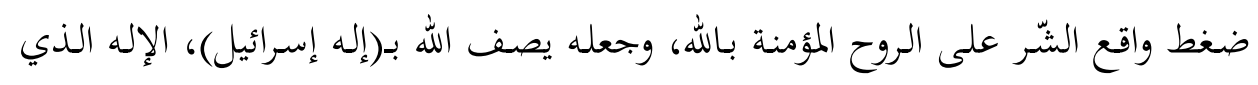

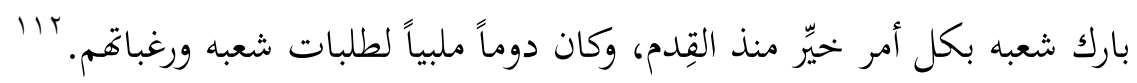
ولم يعجز العقل اليهودي عن إيجاد نصوص دينية توضح سبب الدخول غير العقلاني

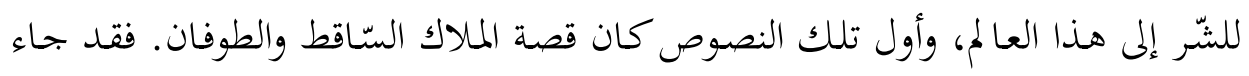

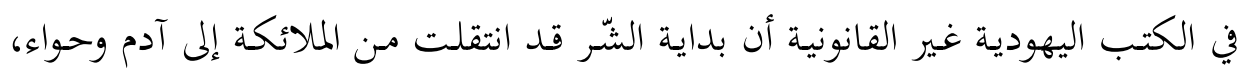

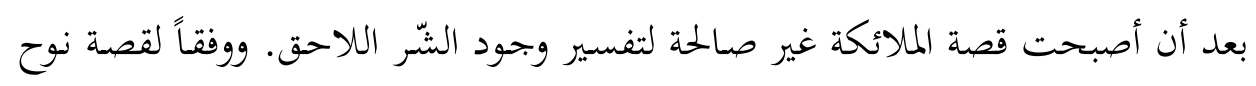

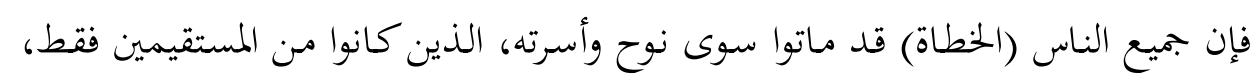

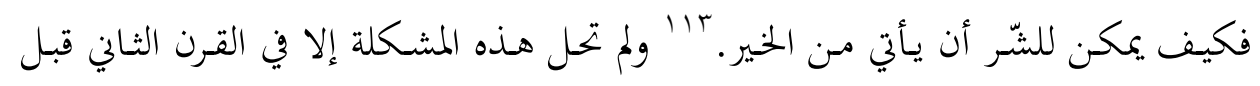

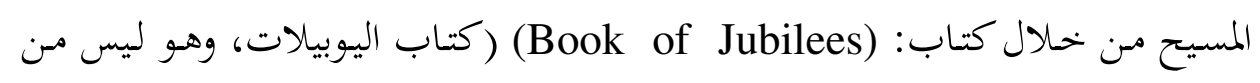

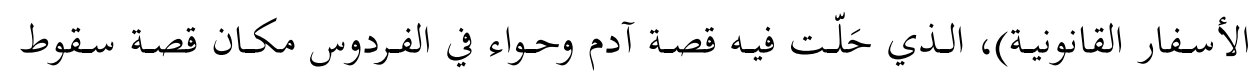

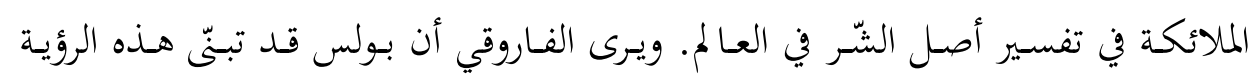

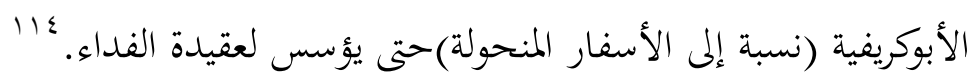

إن إعادة التقويم المسيحي للنظرة اليهودية حول مسألة السقوط لم تنجح في توظيف

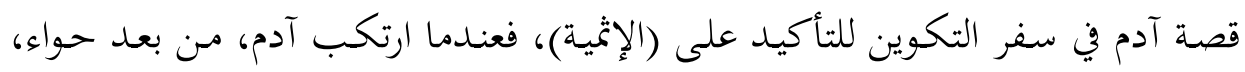

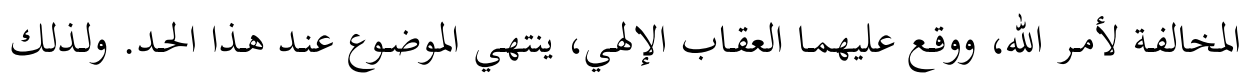


يرى الفـاروقي أن قصة آدم هذه تمثل دليلاً ضعيفاً على نظرية (الإثمية)، وعلى الخطيئة

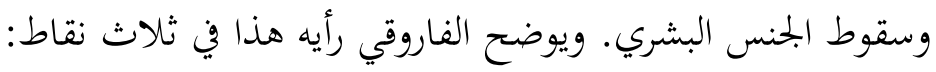

أولاً: القول بأن خطيئة إنسان واحم، التي هي خطيئة أخلاقية، أصبحت متصلة

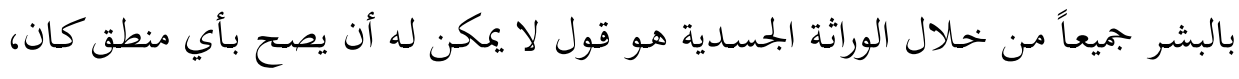

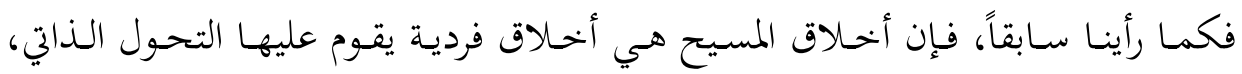

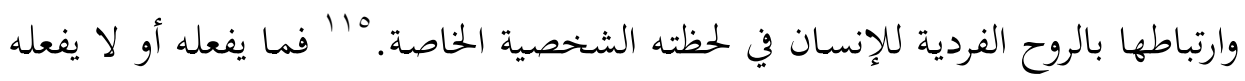

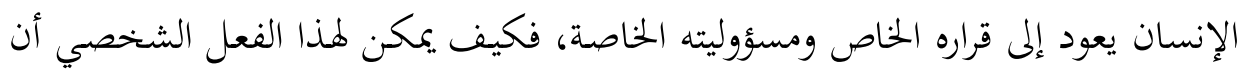
يصبح مسؤولية لشخص آخر أو للناس جميعاً؟

ثانياً: أنْ يصبح عقاب إنسان واحد عقاباً للناس جميعاً هو سلوك مستحيل؛ لأنه

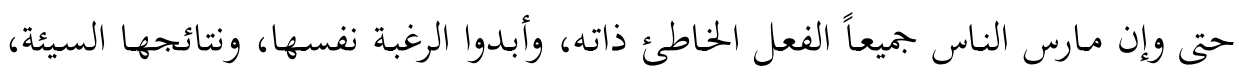

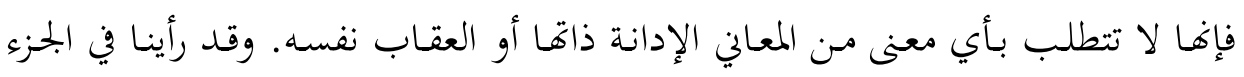

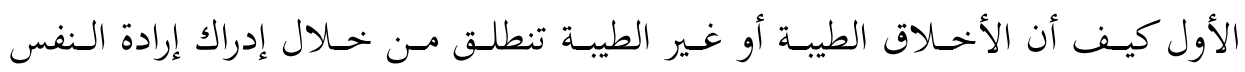

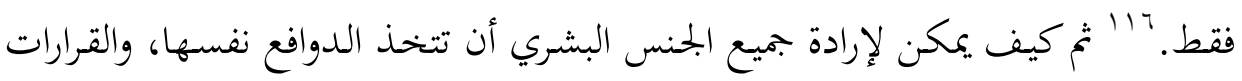

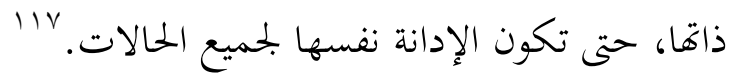
ثالثاً: إن مضمون الفعل الخاطئ لآدم، وهو على وجهه التحديد "الأكل مـ شجرة

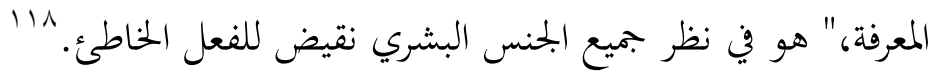

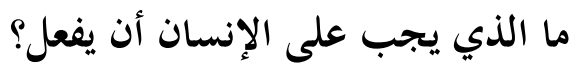

يناقش الفاروقي في هذا الفصل الفعل الإنساني في المنظور المسيحي. ويبدأ حديثه

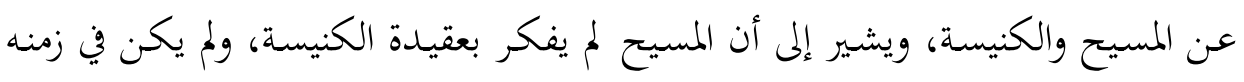

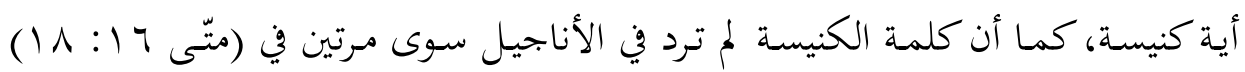


"فوق هذه الصخرة سوف أبني كنيستي،" وذلك في الإشارة إلى بطرس. وأما الموضع الثاني

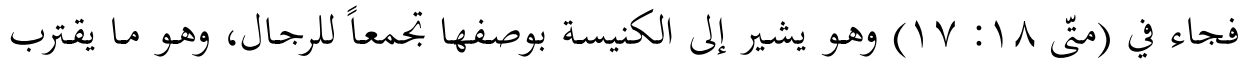

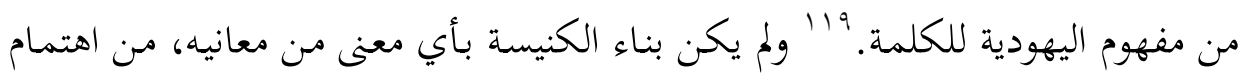

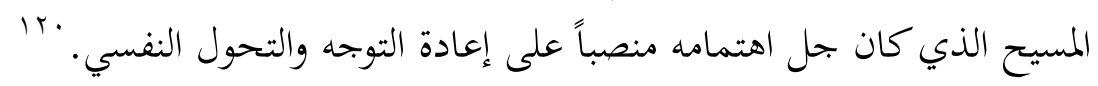

وعن علاقة المسيحية بالمتمع يقرُّ الفاروقي بأن معظم المفكرين المسيحيين يؤيدون

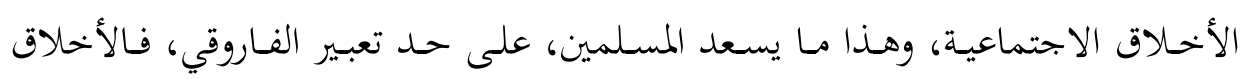
الاجتماعية هي تحقيق لإرادة الله إلى جانب الأخحلاق الفردية، كما أن الأولى هي تكميل

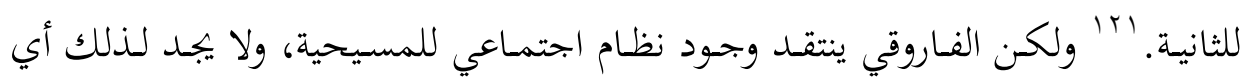
أساس في النصوص الإبخيلية.

ويناقش الفاروقي بعض الطروحات المسيحية التي تعالج هذه القضية كما هو الحال مع ويليام تمبل (William Temple)، و ووبرت اوين (Robert Owen)، ودعوةًا إلى بحتمع يكون فيه الناس جميعاً أعضاء فيه من خلال فضيلة إنسانيتهم، وليس من خهلال

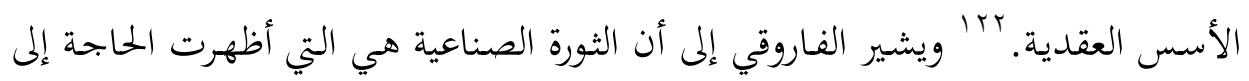

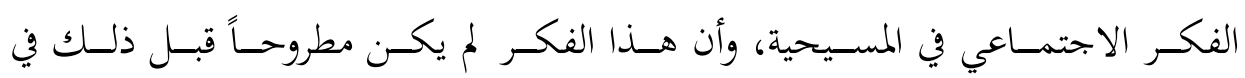
المسيحية. rr ' وعلى ذلك فإن إقامة نظام اجتماعي في المسيحية يتطلب إجراء تعديلات

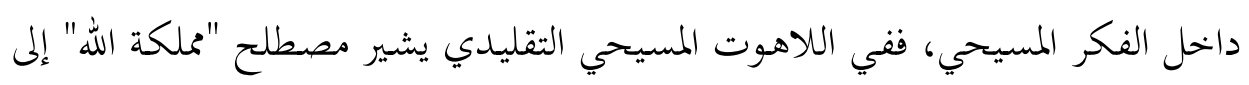
الكنيسة وليس المجتمع، ومن هنا فإن الدعوات التي تنادي بإيجاد نظام اجتماعي مسيحي

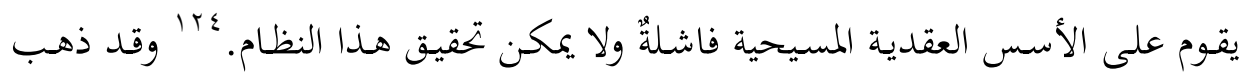
اللاهوت المسيحي المعاصر إلى حل هذه المشكلة من خلال القول بأن "ملكوت الله" هو

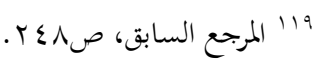

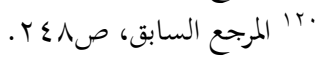

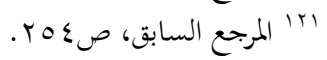

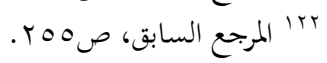

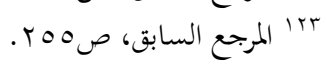

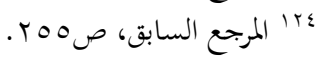


كل من الكنيسة والبحتمع. "إبا إلا أن المشكلة الكبرى تبقى في النظرة المسيحية نفسها،

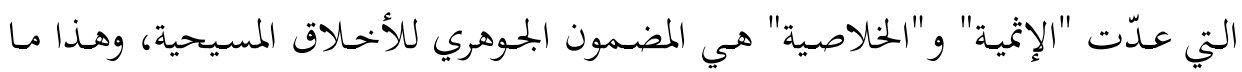

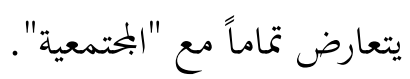

وأمـا مـا يسمى بـ"لاهـوت المستقبل" الذي ينطلق مـن أن "ملكوت الله" هـو هـذا

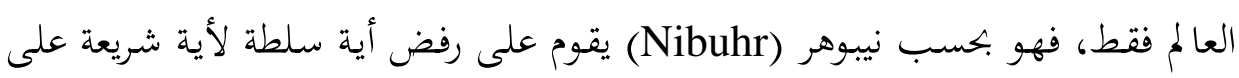

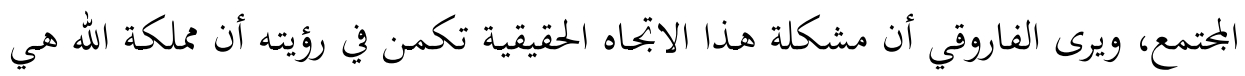

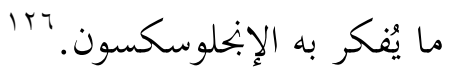

ويؤكد الفاروقي مرة أخرى أن المسيح لم ينظم كنيسة نظراً لاهتمامه بالمشاكل الأكثر

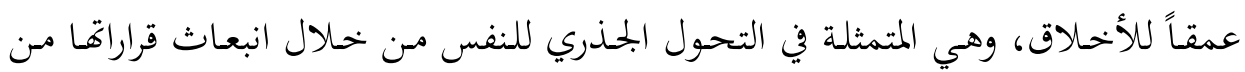

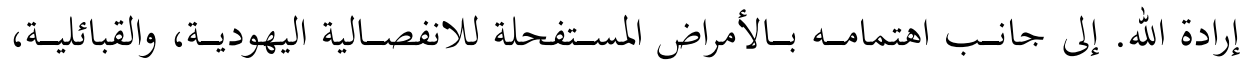

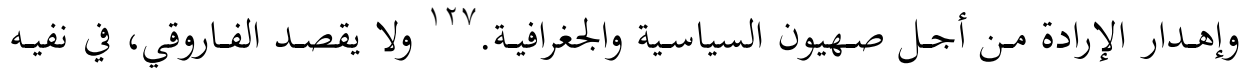

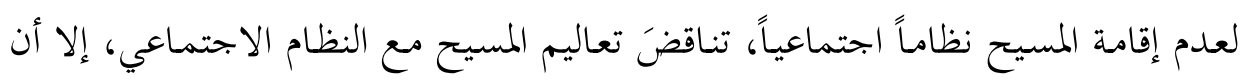

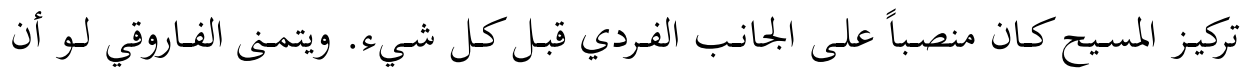

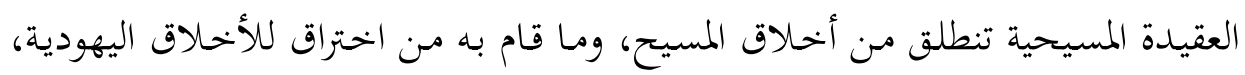

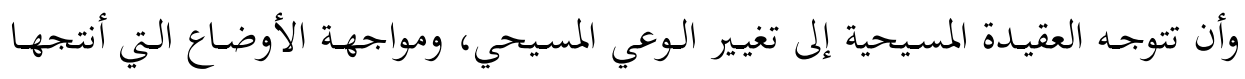

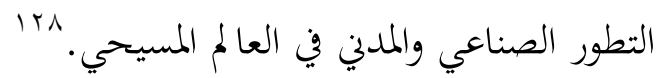

ويرى الفاروقي أن حدوث هذا التغير في الوعي المسيحي، سوف يكون بمثابة بداية

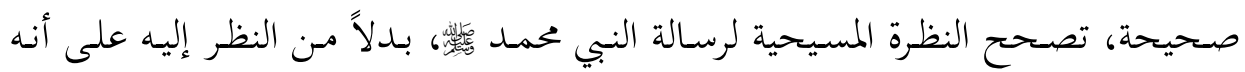

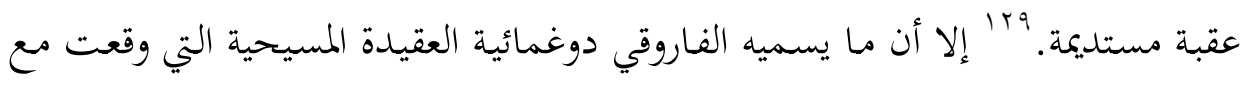

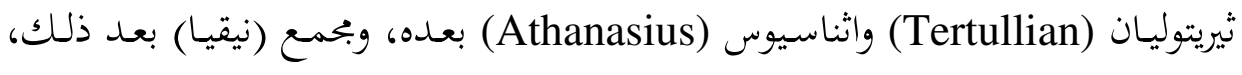

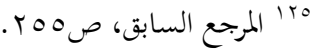

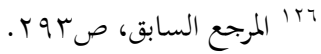

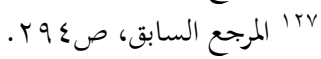

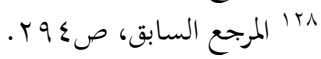

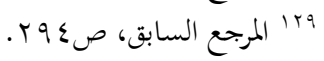




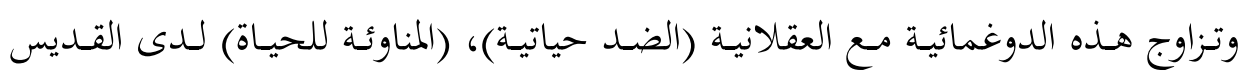
أوغسطين في بحمع خلقيدونيا، كل ذلك يجول دون تحقيق ذلك التغيير.

ويــرى الفــاروقي أن الفكـر المسـيحي لا يمثـل أخـلاق المسـيح، وأنسه بــات معاديـاً

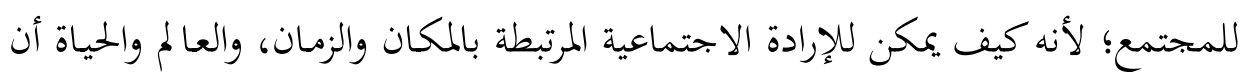

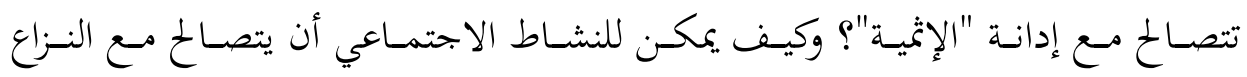
الحلاصي، الذي يعني أن جميع الاحتياجات الإنسانية التي ينبغي القيام بها قد تحققت مرة

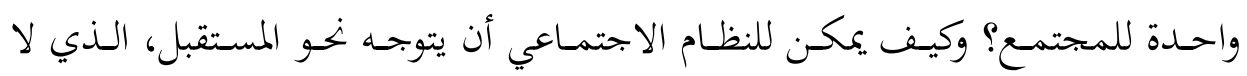

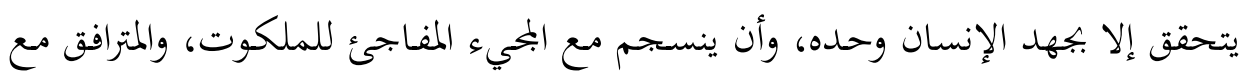

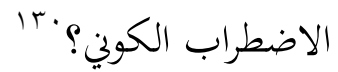

وفي الخاتمة تعرّض الفاروقي للابتعاد الذي وقع للتعاليم المسيحية السائدة عن تعاليم

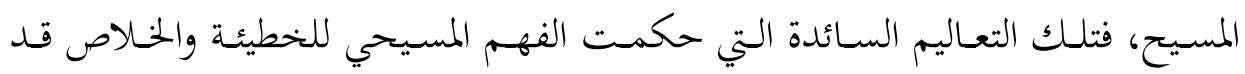

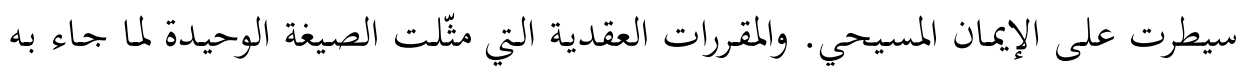

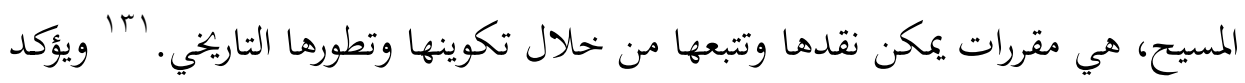

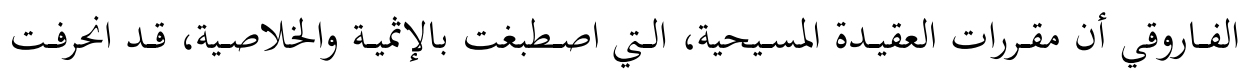
بعيـاً عـن العقيـدة التي تتصـف بـالتحرر مـن التنـاقض والانسـجام مـع تـاريخ النبـوات.

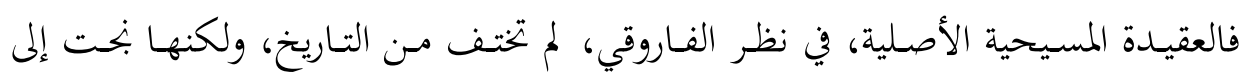

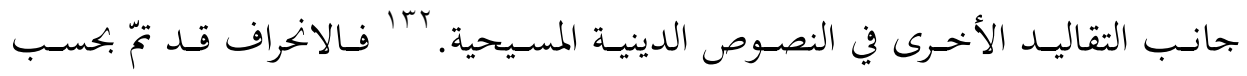
الفاروقي من خلال حكم السلطة نفسها التي اعتمدت التحريف، وهذه السلطة كانت هي كنيسة العاصمة الإمبراطورية؛ روما، التي دعت نفسها الكنيسة الكاثوليكية والرسولية

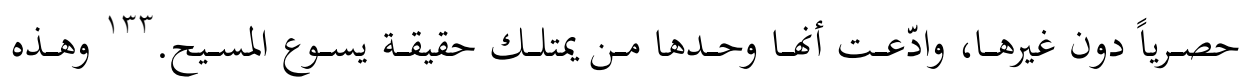

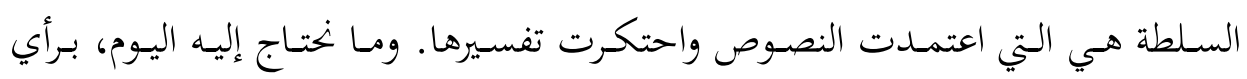

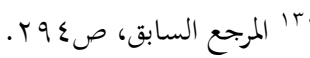

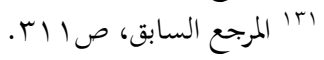

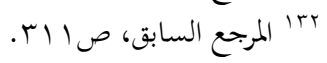

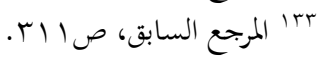


الفـاروقي، ليس أقل مـن الإصلاح، ولكنه ليس إصلاحاً كذلك الذي قام بـه لوثر ضد

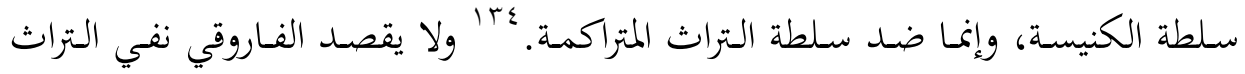
المسيحي واستبعاده برمته، وإنما بتحقيق المسيحيين التحرر في علاقتهم بالترا،ث بداية من

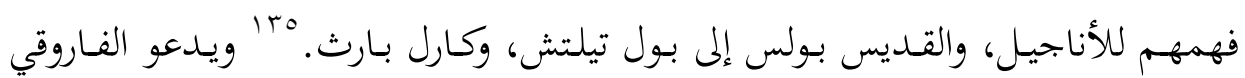

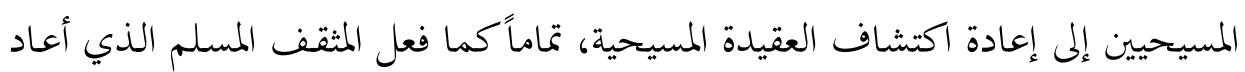
اكتشاف الصورة الأصلية لإِسلام، ودرّب نفسه على استبعاد الغثاء المتراكم عبر القرون. وهنـا يرى الفـاروقي مستوى آخر للحوار الإسـلامي المسيحي، الذي يقوم على جدلية

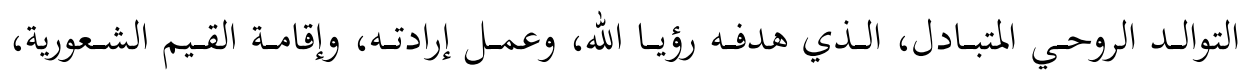
والفعلية في المكان والزمان.

خاتمة:

يمثل كتـاب الأخهاق المسـيحية تطبيقـاً عمليـا للمبـادئ العامـة المعيارية التي وضعها الفـاروقي لدراسـة الأديـان، والكشـف عـن أصسولها الأولى، وتطوراتها المتعاقبـة، وإمكانيـة الحكم عليها بعيداً عن النظرة الذاتية وأحكامها المسبقة. لقد بجح الفاروقي إلى حد كبير في إعادة اكشاف الديانة المسيحية، مـ خلال تتبعه للمهاد التاريخي والثقافي الذي ظهرت فيه المسيحية، وأسهم في تكوين مقولاتها العقدية؛

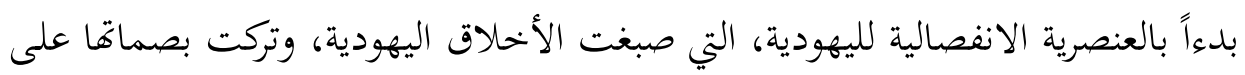
النص الديني للعهد القديم، ومروراً بالمؤثرات الهلينية، والغنوصية، والمانوية، والزرادشتية، التي

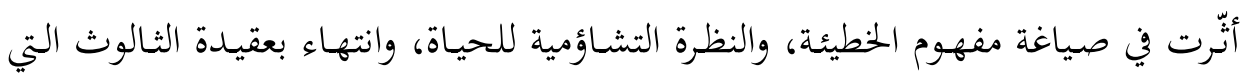
رأى فيها الفاروقي امتداداً منطقياً، ومتطلباً حتمياً لعقيدة الخطيئة. رأى الفـاروقي أن جـذور المشـكلة الأساسية في الفكـر الـديني المسـيحي، تكمـن في

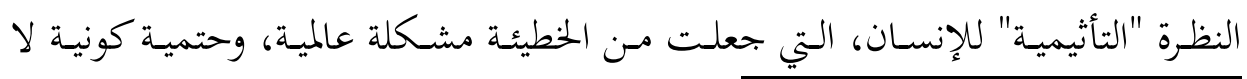


مناص للهروب منها، إلا بالتدخل الإلهي الحلاصي. وأثبت الفـاروقي أن أخهاق المسيح

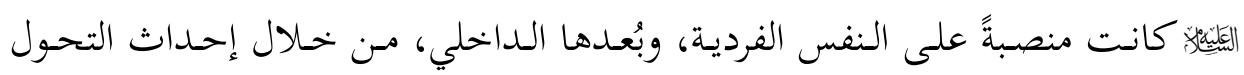
الجذري لتلك لنفس، بعيداً عن البناء الاجتماعي والتشريعي. وأظهر الفـاروقي كفـاءة كبيرة في التعامل مـع المصـادر المسيحية، والدراسـات الغربية ومناهجهـا المعاصـرة، الأمـر الـذي أكسـب تحليلاتـه الفكريـة، وطروحاتـه النقديـة قـوةً وتماسكاً، قلما بجدها لدى جل الكتّاب المسلمين المعاصرين. 